\title{
Başarımla İlgili Duygular Anketinin Öğretmen Adayları için Geçerleme Çalışması ve Kısa Formu*
}

\section{A Validation Study and Short form of Achievement Emotion Questionnaire for Preservice Teachers}

\author{
Eda BAKIR ${ }^{1}$, Nilüfer ATMAN USLU², Yasemin KOÇAK USLUEL ${ }^{3}$
}

\begin{abstract}
${ }^{1}$ Sorumlu Yazar, Araş. Gör., Bilgisayar ve Öğretim Teknolojileri Eğitimi Bölümü, Ĕ̆gitim Fakültesi, Recep Tayyip Erdoğan Üniversitesi, Türkiye, eda.bakir@erdogan.edu.tr, (https://orcid.org/ 0000-0001-5178-486X)

${ }^{2}$ Dr. Öğrt. Üyesi, Bilgisayar ve Öğretim Teknolojileri Ĕ̆itimi Bölümü,Ĕ̈itim Fakültesi, Manisa Celal Bayar Üniversitesi, Türkiye, atmanuslu@gmail.com, (https://orcid.org/0000-0003-23224210)

${ }^{3}$ Prof. Dr., Bilgisayar ve Öğretim Teknolojileri Ĕ̆itimi Bölümü,Eğitim Fakültesi, Hacettepe Üniversitesi,Türkiye, kocak@hacettepe.edu.tr, (https://orcid.org/0000-0002-6147-3333)
\end{abstract}

Gelis Tarihi: 19.04.2021

Kabul Tarihi: 30.11 .2021

\section{ÖZ}

Bu çalışmanın iki amacı bulunmaktadır. Birincisi, Pekrun, Goetz ve Perry (2005) tarafından geliştirilen ve Can, Emmioğlu Sarıkaya ve Bardakçı (2020) tarafından lise öğrencileri için Türkçeye uyarlaması yapılan Başarı Duyguları Anketi'nin, dersle ilgili duygular bölümünün öğretmen adayları için geçerleme çalışmasını yapmaktır. İkincisi, yapılan geçerleme çalışmasının bulgularından hareketle anketin kısa formunun oluşturularak geçerlik ve güvenirliğinin irdelenmesidir. Çalışma grubu, Türkiye'de altı devlet üniversitesinde öğrenim gören 308 öğretmen adayından oluşmaktadır. Verilerin analizinde, birinci ve ikinci düzey faktör analizi yapılmış, Cronbach's alpha ve yapısal güvenirlik katsayıları hesaplanmıştır. Verilerin analizi sonucunda uyum iyiliği indisleri ve yakınsama geçerliği ölçütlerine uymayan maddeler çıkarılmış; umutsuzluk duygusunun tek faktörlü yapıda, diğer duyguların üç faktörlü ve ikinci düzey faktör yapısında doğrulandığı bulgusuna ulaşılmıştır. Doğrulanan üç faktörlü duygu modelleri için Cronbach's alpha iç tutarlılık katsayıları 0.60 ve 0.83 arasında değişirken tek faktörlü umutsuzluk duygusu için 0.79 olarak bulunmuştur. Yapısal güvenirlik katsayısı üç faktörlü duygu modelleri için 0.63 ve 0.87 arasında, tek faktörlü umutsuzluk duygusunda 0.79 olarak hesaplanmıştır. Bu bulgulardan hareketle ölçme aracının sekiz faktör 46 maddeden oluştuğu sonucuna ulaşılmıştır. Geçerleme çalışması sonucunda 46 maddeden oluşan anketin kısa versiyonu, kapsam geçerliği gözetilerek yüksek faktör yükü veren maddelerin seçilmesi yoluyla oluşturulmuştur. Doğrulayıcı faktör analizi sonucunda, uyum indisleri iyi ve mükemmel aralığında olan 24 maddelik kısa formun Cronbach Alpha değeri 0.75 olarak; yapısal güvenirlik katsayıları 0.73 ve 0.86 olarak bulunmuştur. Ölçme aracında yer alan maddelerin başarım (performans) temelinde olması nedeniyle, aracın içeriğini de daha uygun yansıttığı gerekçesiyle ölçme aracına "başarımla ilgili duygular" adı verilmiştir.

Anahtar Kelimeler: Başarımla ilgili duygular, Kontrol-Değer Kuramı, çevrimiçi öğrenme ortamları, öğretmen adaylar1.

\footnotetext{
* Bu çalışma ilk yazarın doktora tezinin bir bölümünden üretilmiştir.
} 


\begin{abstract}
This study has two aims. The first is to validate Achievement Emotion Questionnaire- Class Related Emotions part for preservice teachers, which was developed by Pekrun, Goetz and Perry (2005) and adapted to Turkish by Can, Emmioğlu Sarıkaya and Bardakçı (2020) for high school students. Second, based on the findings of first study, the short form of the AEQ was created and examined for validity and reliability. Participants are 308 preservice teachers from six state universities in Turkey. First and second level confirmatory factor analysis was performed, Cronbach's alpha and Composite Reliability were calculated. The items which did not meet the criterias of fit indices and validity were removed and it was found that hopelessness was confirmed as single factor model and the other emotions as three-factor model and second order model. While Cronbach's alpha for the confirmed three-factor models ranged between 0.60 and 0.83 , it was found to be 0.79 for hopelessness. Composite reliability was calculated as between 0.63 and 0.87 for three-factor model and 0.79 for single-factor hopelessness. Based on these findings, it was concluded that the AEQ consisted of eight factors and 46 items. Based on the findings of the first study, the short form of AEQ was created by selecting the items with high factor loadings, considering the content validity. According to the confirmatory factor analysis Cronbach Alpha of the 24-items short form was 0.75 and have good and perfect fit indices also composite reliability were found as between 0.73 and 0.86 .
\end{abstract}

Keywords: Achievement emotions, Control-Value Theory, online learning environments, preservice teachers.

\title{
GİRIŞ
}

Alanyazında, duyguların öğrenmeyi, dikkati, bilişi, belleği, karar verme süreçlerini, öğrenenlerin kullandıkları öğrenme stratejilerini, öz düzenlemeli öğrenmelerini, bağlılıklarını, akademik performanslarını ve başarılarını etkilediği dile getirilmektedir (Hayat, Shateri, Amini ve Shokrpour, 2020; ImmordinoYang ve Damasio, 2007; Obergriesser ve Stoeger, 2020; Park ve Lim, 2019; Pekrun, 2006; Pekrun ve Perry, 2014; Raccanello, Brondino, Crescentini, Castelli ve Calvo, 2021; Schrader ve Kalyuga, 2020; Wosnitza ve Volet, 2005; You ve Kang, 2014). Okul ortamında yaşanan olumlu duygusal deneyimlerin akademik başarıya katkıda bulunduğu bilinmektedir (Fried, 2011; Parkinson ve Totterdel, 1999; Pekrun, 2019). Bununla birlikte Pekrun (1992), duygu ve öğrenme ilişkisinin basit bir ilişki olmadığını belirtmiştir. Duyguların, öğrenme sürecinin herhangi bir aşamasında, farklı öğrenenler için tamamen farklı, hatta bazı durumlarda tam tersi etkilere yol açabileceği ileri sürülmüștür (Rientiers ve Rivers, 2014). Pozitif duyguların öğrenme ve performans ile pozitif ilişkili olduğu, negatif duyguların ise öğrenme, motivasyon ve performans ile negatif ilişkili olduğu iddia edilmektedir (Pekrun, 2006). Fakat bazı duyguların bağlam özellikleri dikkate alındığında bu genel kanının aksine sonuçlara ulaşıldığı; örneğin kaygı duygusunun, bazı öğrenenler için motivasyon ve performans ile negatif ilişkili iken bazı durumlarda pozitif bir katkı sağladığı ortaya konulmuştur (Hilliard, Kear, Donelan ve Heaney, 2020). Buradan hareketle, pozitif duyguların pozitif öğrenme ve performansa ve öğrenme çıktılarına, negatif duyguların negatif çıktılara sebep olduğu çıkarımı gibi genellemelerden kaçınılmasının uygun olacağı söylenebilir. Bu noktada, duyguların oluştuğu bağlamın önemi ortaya çıkmaktadır.

Alanyazındaki çalışmalara öğrenme ortamı açısından bakıldığında çalışmaların çoğunun yüz yüze sınıf ortamlarında yapıldığı görülmektedir. Çevrimiçi öğrenme ortamlarının eğitimde s1klıkla kullanılmaya başlanması (Lajoie, Pekrun, Azevedo ve Leighton, 2019; Stephan, Gläser Zikuda ve Markus, 2019); değişen öğretmen ve öğrenci rollerinin, çevrimiçi derslerin değişen formatlarının bu ortamlarda duygu ile ilgili çalışmalara gereksinimi beraberinde getirdiği ifade edilmektedir (Regan ve diğerleri, 2012). Nitekim yaşanan Covid-19 salgın süreci çevrimiçi öğrenme ortamlarının kullanılmasını zorunlu kılmış ve fiziksel eğitim ortamları tamamen çevrimiçi bir ortama taşınmıştır. 
Eğitsel bağlamdaki duygularla ilgili olan Kontrol-Değer Kuramına göre, bireyin bir olay, görev ya da durum karşısında algıladığı kontrol ve öznel olarak olaya, duruma veya göreve verdiği değerin değerlendirilmesi, akademik bağlamlarda duygulara öncülük etmektedir (Pekrun, 2000; Pekrun, 2006; Pekrun, Goetz, Frenzel, Barchfeld ve Perry, 2011). Kontrol-Değer Kuramında (Pekrun, 2000), Şekil 1'de görülen yakınsak öncüller olarak ifade edilen kontrol ve değer değerlendirmelerine ek olarak, uzak öncüllerin örneğin bireyin başarı ile ilgili hedeflerinin, sosyal ve kültürel öncüllerin (öğretimin kalitesi ve başarı ile ilgili beklentiler gibi) eğitim ortamlarında duyguların belirleyicileri olarak nitelendirilmiştir (Pekrun ve diğerleri, 2011). Duygular ise öğrenme stratejilerini, öğrenmeye yönelik güdüyü, öğrenmenin öz düzenlemesini ve öğrenci başarısını etkilemektedir. Kontrol-Değer Kuramı, duyguların öğrenme çıktılarını etkilerken öğrenme çıktılarının da sonraki duyguları etkilediğini de ifade etmiştir. Şekil 1' de görüldüğü gibi Kontrol-Değer Kuramı, bir başarı durumu ile ilgili olan duygulara çeşitli yaklaşımlardan gelen yapıları ve varsayımları bütünleştirmekte ve bir çerçeve sağlamaktadır (Pekrun, Frenzel, Goetz ve Perry, 2007).

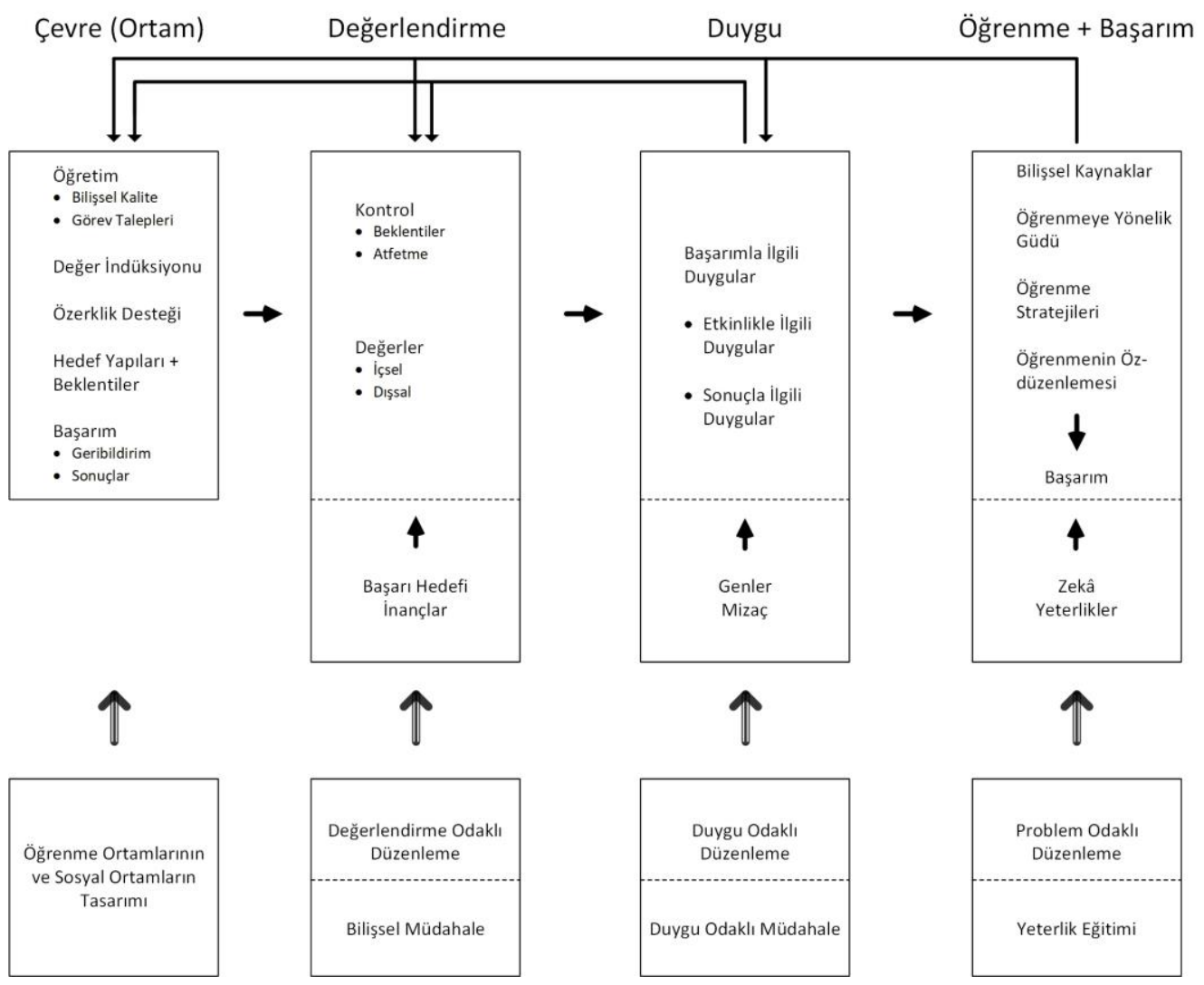

Şekil 1. Kontrol-Değer Kuramı (Pekrun, 2006)

Başarımla ilgili duygular, bir etkinliğin ya da görevin sonucunda elde edilen başarı ya da başarısızlığı takip eden duygular olarak ifade edilmiş, fakat daha sonra, bir etkinlik ya da uygulama esnasında ortaya çıkan duygular da bu kategori içinde değerlendirilmiştir (Pekrun ve diğerleri, 2011). $\mathrm{Bu}$ nedenle ölçme aracinda yer alan maddelerin başarım (performans) temelinde olması nedeniyle, aracın içeriğini de daha uygun yansıttığı gerekçesiyle ölçme aracına "başarımla ilgili duygular" adı verilmiştir. Akademik ortamlarda yaşanan her duygu başarımla ilgili bir duygu olarak nitelendirilmeyebilir. Örneğin akademik ortamlarda yaşanan sosyal duygular, bir kişinin çalışma grubundaki bireyler için duyduğu empati duygusu ya da grup içinde yaşadığı kıskançlık duygusu başarımla ilgili duygular olarak ifade edilmemektedir (Pekrun ve Stephens, 2010). Duygular Kontrol-Değer Kuramı bağlamında 
değerliklerine (negatif ya da pozitif), etkinleştirme seviyelerine (harekete geçirici ya da pasifleştirici) ya da hedef odağına göre (öğrenme ortamlarında duygular başarı etkinlikleri ile ilgili olabildiği gibi başarı sonuçları ile ilgili duygular olarak) sınıflandırılmaktadır. Örneğin öğrencinin ilginç bulduğu bir konuyla ilgili dersi dinlediğinde oluşan keyif duygusu bir uygulama(etkinlik) odaklı ya da uygulama esnasında hissedilen bir duygu türü iken, düşük sınav notu sonucu oluşan hayal kırıklığı, sonuç duygusu (çıktı) ya da sonuç odaklı bir duygu örneğidir (Harley, Lajoie, Tressel ve Jarrell, 2018). Öğrenciler farklı akademik alanlarda (İngilizce, matematik, fen bilimleri..) ve farklı akademik faaliyetlerde bulunurken (bir derse girmek, ev ödevi yapmak, sınava girmek gibi) farklı duygusal deneyimler (keyif, umutsuzluk, kaygı gibi) yaşamaktadırlar (Sanchez, Monteiro, Mata, Santos ve Gomes, 2020). Akademik ortamdaki duyguların bu sınıflandırması, duygunun öğrenmedeki güdüsel ve bilişsel faktörler üzerindeki etkilerini anlamak için önemli olarak değerlendirilmektedir (Peklaj ve Pecjak, 2011). Bu etkileri anlayabilmek ve ölçebilmek için Pekrun, Goetz ve Perry (2005) eğitsel bağlamda sınıflandırdıkları duygular için Başarımla İlgili Duygular Anketini (BIDA) geliștirmișlerdir. BİDA, başarımla ilgili duyguları değerlendirmek için tasarlanmış çok boyutlu öz bildirime dayalı bir ölçme aracıdır. Duyguların işlevlerini analiz etmek ve eğitsel bağlamlarda bu duyguları değerlendirmek için kuramsal temelli ölçüm araçlarına olan ihtiyaç doğrultusunda bu anket, Kontrol-Değer Kuramını ve üç akademik bağlamı temel alarak dersle, sınavla ve öğrenme ile ilgili duygular olmak üzere üç bölümde hazırlanmıştır (Pekrun ve diğerleri, 2011). Dokuz ayrı duyguyu içeren ankette, keyif, umut, gurur, sıkılma, rahatlama, öfke, kayg1, utanma ve umutsuzluk duygusu yer almaktadır. Alanyazında değiş̧en öğrenme ortamlarının dersle ilgili duygularda değişiklik gösterdiği (Regan ve diğerleri, 2012) ve ders esnasında öğrencilerin duygularının çok önemli olduğu (Krithika, Lakshmi ve Priya, 2016) ifade edilmektedir. Buradan hareketle dersle ilgili duygular bölümünün, öğretmen adayları ve çevrimiçi öğrenme bağlamında geçerleme çalışması yapılmıştır.

Başarımla ilgili duyguların bağlama özgü olduğu düşünüldüğünde çevrimiçi öğrenme ortamlarındaki başarımla ilgili duyguların da farklı olması beklenmektedir (D'Errico, Paciello ve Cerniglia, 2016). Marchand ve Gutierrez (2012) belirttiği gibi duyguların çevrimiçi öğrenme ortamlarında nasıl işlediği ve akademik duygularla ilgili öngörülerin ve sonuçların geleneksel sınıf ortamlarından benzer veya farklı olup olmadığı noktası araştırmaya değer olarak ifade edilmektedir. Ayrıca ulusal alanyazında, duygu ile ilgili yapılacak olan araştırmalarda üniversite düzeyinde ve çevrimiçi öğrenme ortamında geçerliği ve güvenirliği kanıtlanmış bir ölçme aracına gereksinim olduğu ifade edilebilir. Uyarlaması yapılan anketin (Can, Emmioğlu Sarıkaya ve Bardakçı, 2020) yüz yüze eğitim ortamları temel alınarak yapılmış olması, çevrimiçi ortamda lisans öğrencileri düzeyinde geçerlik ve güvenirliği sağlanmış duygu ile ilgili Türkçe bir ölçme aracının bulunmaması nedeniyle geçerleme çalışması yapılmıştır. Hambleton ve Patsula'nın (1999) belirttiği gibi geçerliği ve güvenirliği sağlanmış bir ölçme aracının uyarlamasının vereceği güven duygusunun yeni oluşturulacak olana kıyasla daha fazla olacağı nedeni ile bu çalışma gerçekleştirilmiştir. Bu noktalardan hareketle bu çalışmanın iki amacı bulunmaktadır. Bunlardan birincisi BİDA'nın dersle ilgili duygular bölümünün çevrimiçi öğrenme bağlamında, öğretmen adayları için geçerleme çalışmasının yapılmasıdır. Bu amaca ek olarak, duyguları belirlemek üzere geliştirilmiş ölçeklerde madde sayısının fazla olması daha uzun yanıtlama süreleri gerektirmektedir. BİDA'da dersle ilgili duygular 80 madde ile ölçülmektedir. Bu durumda, öğrencilerin duygularını ölçmek üzere tasarlanmış bir ölçme aracını yanıtlama esnasında öğrencilerin duyguları değişiklik gösterebilmektedir. Örneğin ölçek doldurma sürecinin başlangıcında mutluluk, heyecan gibi duyguları yaşayan öğrencilerin uzun ölçek yapısından ya da ölçeği yanıtlama süresinden dolayı sıkılma ve öfke gibi olumsuz duygu durumlarına dönüşebilme potansiyeli söz konusudur. $\mathrm{Bu}$ durumlar ilgili ölçeklerin geçerliği ile ilgili tartışmaları da beraberinde getirmektedir. Dolayısıyla, diğer psikolojik yapıların aksine duyguların değişkenlik gösterme potansiyeli nedeniyle kısa formlarının geliştirilmesine gereksinim olduğu ileri sürülebilir. Buradan hareketle bu çalışmanın ikinci amacı, yapılan 
geçerleme çalışmasının bulgularından hareketle BİDA'nın kısa formunun oluşturularak geçerlik ve güvenirlik hesaplamalarının yapılmasıdır.

\section{YÖNTEM}

\subsection{Katılımcilar}

Çalışmanın katılımcıları ölçme aracını gönüllü olarak yanıtlayan Türkiye'de altı devlet üniversitesinin eğitim fakültesinde öğrenim görmekte olan 308 öğretmen adayından oluşmaktadır. Öğretmen adaylarının demografik özelliklerine göre dağılımı Tablo 1'de sunulmuştur.

Tablo 1. Katılımcıların Demografik Özellikleri

\begin{tabular}{llll}
\hline & & $f$ & $\%$ \\
\hline Cinsiyet & Kadın & 215 & 70 \\
Üniversite & Erkek & 93 & 30 \\
& Muş Alparslan Üniversitesi & 45 & 14,6 \\
& Giresun Üniversitesi & 100 & 32,46 \\
& Artvin Çoruh Üniversitesi & 25 & 8,11 \\
& Recep Tayyip Erdoğan Üniversitesi & 93 & 30,1 \\
& Trakya Üniversitesi & 17 & 5,51 \\
Dersler & Amasya Üniversitesi & 28 & 9,09 \\
& Öğretim Teknolojileri & 169 & 54,9 \\
& Sinıf Yönetimi & 46 & 14,9 \\
& Öğretmenlik Mesleğine Giriş̧ & 46 & 14,9 \\
& Rehberlik & 24 & 7,8 \\
& Özel Öğretim Yöntemleri & 12 & 3,9 \\
& Gelişim ve Öğrenme & 6 & 2,0 \\
& Diğer & 5 & 1,6 \\
\hline
\end{tabular}

Tablo 1'e göre kat1lımcıların \%70'i kadın, \%30’u erkek; \% 32,4‘ü Giresun Üniversitesi, \% 30,1'i Recep Tayyip Erdoğan Üniversitesi, \% 14,6's1 Muş Alparslan Üniversitesi, \% 8,1'i Artvin Çoruh Üniversitesi, \%9,01 ' $\mathrm{i}$ Amasya Üniversitesi ve \% 5,5'i ise Trakya Üniversitesinde öğrenim görmektedir. Veri toplama sürecinden önce sözü edilen üniversitelerde anketi uygulamak için etik kurul izni alınmış ve katılımcıların gönüllüğü esas alınmıştır. Öğretmen adaylarından ölçme aracını yanıtlama sürecinde, öğretmenlik meslek bilgisi derslerinden birini seçerek bu derse ilişkin duygularını belirtmeleri istenmiştir. Buna göre öğrencilerin duygularını ifade ettikleri derslerin dağılımı incelendiğinde \%54,9'unun öğretim teknolojileri, \%14,9'unun sınıf yönetimi, \%14,9'unun öğretmenlik mesleğine giriş, \%7,8'inin rehberlik dersini seçtiği saptanmıştır. Bununla birlikte, özel öğretim yöntemleri I-II $(\% 3,9)$ gelişim ve öğrenme $(\% 2)$ ve diğer meslek dersleri $(\% 1,6)$ ögretmen adaylarının anketi yanıtlamak için seçtikleri dersler arasında yer almıştır.

\subsection{Başarımla İlgili Duygular Anketi (BİDA)}

BİDA, başarımla ilgili duyguları değerlendirmek için tasarlanmış çok boyutlu öz bildirime dayalı bir ölçme aracıdır. Pekrun ve diğerleri (2005) tarafından geliştirilen ankette (a) dersle ilgili, (b) öğrenme ile ilgili, c)sınavla ilgili duygular olmak üzere üç kategori bulunmaktadır. Dersle ilgili duygular kategorisinde, öğrenenlerin sınıf ortamında deneyimlemiş olduğu duyguların ölçülmesine yönelik maddeler bulunmaktadır. Anket duyguları, ders öncesi, ders esnası ve ders sonundaki duygular olarak zamansal olarak da sınıflayarak oluşturulmuştur. Buna göre dersle ilgili duygular kategorisinde, gurur (9 madde), kaygı (12 madde), keyif (10 madde), öfke (9 madde), s1k1lma (11 madde) umut ( 8 madde), umutsuzluk (10 madde), utanma (11 madde) olmak üzere sekiz faktör ve 80 madde yer almaktadır. Sözü edilen bu sekiz duygunun yedisinin 
duygulanımsal, bilişsel, güdüsel ve fizyolojik olmak üzere dört alt boyutu bulunmaktadır. Umut duygusu ise bilişsel, duygulanımsal ve güdüsel olmak üzere üç alt boyut ile temsil edilmektedir. Anketin yapı geçerliği için tek faktörlü model, dört veya üç faktörlü model ve ikinci düzey faktör analizi yapılmıştır (Pekrun ve diğerleri, 2005). Anketin orijinalinde bu üç model doğrulanmıştır. BIDA modüler bir yapıya sahip olup, faktörleri birbirinden bağımsız bir biçimde kullanılabilmektedir. Ankette yanıtlar 1, "kesinlikle katılmıyorum" ve 5, "kesinlikle kat1lıyorum" ifadelerini yansıtacak şekilde 5'li Likert yapısında hazırlanmıştır.

Türkçeye Can, Emmioğlu Sarıkaya ve Bardakçı (2020) tarafından lise öğrencileri için uyarlanan BİDA'nın dersle ilgili duygular bölümünün Cronbach Alpha iç tutarlılık katsayıları, 'keyif' için 0.87; 'gurur' için 0.82; 'kaygı' için 0.80; 'öfke' için 0.84 , 'umut' duygusu için 0.83 , 'umutsuzluk' için 0.85 , 'utanma' için 0.88 ve 'sıkılma' için 0.92 olarak hesaplanmıştır.

Geçerleme çalışması için uyarlama çalışmasını gerçekleştiren yazarlardan e-posta yoluyla gerekli izinler alınmıștır. Anketin Türkçeye uyarlama sürecinde dil geçerliğinin yapılması nedeniyle bu çalışmada soruların öğretmen adaylarına uygunluğu incelenmiştir. Buna ek olarak çevrimiçi öğrenme ortamındaki duyguların belirlenmek istenmesi nedeniyle yönergede düzenleme yapılmıştır. Son olarak, altı devlet üniversitesinde öğrenim görmekte olan öğretmen adaylarıyla çevrimiçi öğrenme ortamında, anketin elektronik erişim bağlantısı paylaşılarak veriler çevrimiçi ortamda toplanmıştır.

\subsection{Verilerin Analizi}

BİDA'nın geçerleme çalışması için veriler 357 öğretmen adayından toplanmıştır. Altı öğretmen adayının anketi büyük oranda boş bırakması nedeniyle bu katılımcılar veri setinden çıkarılmıştır. Daha sonra uç değerler temizlenmiş ve veri setinde yer alan 308 gözlem ile analiz gerçekleștirilmiştir. Harrington (2009), güçlü bir kuramsal çerçevesi olan ve önceki çalıșmalarla da geçerlik ve güvenirliğine kanıtlar sağlanan araştırmalar için doğrulayıcı faktör analizi yapılabileceğini belirtmiştir. Doğrulayıcı faktör analizi (DFA) gerçekleştirilmeden önce veri setinin tek değişkenli ve çok değişkenli normallik varsayımlarını karşılama durumu incelenmiştir. Alanyazında çarpıklık için \pm 3 ; basıklık için \pm 10 değerleri kullanılmaktadır (Kline, 2005). Yapılan inceleme sonucunda maddelerin çarpıklık değerlerinin -1,56 ile 3,00 arasında, basıklık değerlerinin ise $-1,11$ ile 9,98 arasında değiştiği tespit edilmiştir. Bu değerlere göre veri setinin tek değişkenli normallik varsayımını sağladığı görülmektedir. Bunun yanında çok değişkenli normalliğin test edilmesi için Mardia çok değişkenli kurtosis testi yapılmıştır (Mardia, 1970). Raykov ve Marcoulides (2008), hesaplanan Mardia değerinin, $p(p+2)$ formülünden elde edilecek değerin altında olması gerektiğini gerektiğini belirtmiştir (p: ölçme aracındaki madde sayısı). Bu formüle göre BİDA için elde edilen değer 6560; Mardia değeri ise 79,87 olarak bulunmuştur. Elde edilen bu değer Mardia değerinden küçük olduğu için veri seti çok değişkenli normallik varsayımını da sağladığı sonucuna ulaşılmıştır.

BİDA'nın doğrulayıcı faktör analizleri (DFA) için, maksimum olasılık (ML) tahmin yöntemi kullanılmıştır. Model uyumunu değerlendirmek için, Ki-Kare uyum iyiliği testi, Yaklaşımın Ortalama Karekök Hatası (Root Mean Square Error of Approximation - RMSEA), Karşılaştırmalı Uyum İndisi (Comparative Fit Index- CFI) ve Normed Fit Index (NFI) kullanılmıştır. Alanyazında RMSEA değerinin .05 olması modelin iyi bir uyum gösterdiğini, .05 ve .08 arasında kabul edilebilir olduğunu ve .08 'den yukarısının ise zayıf uyum gösterdiği ve CFI/NFI/TFI değerlerinin .95 'den büyük olduğu durumlarda yüksek uyum, .95 ve .90 arasının kabul edilebilir uyum ve $.90^{\prime}$ dan aşağısının ize zayıf uyum gösterdiği ifade edilmektedir (Hu ve Bentler, 1999). Anketin yakınsama geçerliği için, a) faktör yüklerinin 0.50 değerinden, b) ortalama açıklanan varyans (OAV) değerlerinin de 0.50 değerinin üzerinde olup olmadığ incelenmiştir (Hair, Hult, Ringle ve Sarstedt, 2017). Güvenirlik için Cronbach Alpha iç tutarlılık katsayısı (Hair, Anderson, Tatham ve Black, 1998) ve yapısal güvenirlik katsayısının (Gefen, Straub ve Boudreau, 2000) .70'in üzerinde olması kriteri göz önünde bulundurulmuştur. Anketin kapsam geçerliğinin zedelenmemesi için duygunun çok bileşenli yapısı çerçevesinde kısa form 
oluşturulmuştur. Bu bileşenlerin içinde yüksek faktör yüküne sahip olanların dahil edilmesi ile anketin kısa formu oluşturulmuş ve geçerlik güvenirlik çalışması yapılmıştır.

\section{BULGULAR}

\subsection{Yapı Geçerliği ve Güvenirlik Bulguları}

Anketin modüler bir yapıda olması nedeniyle ankette yer alan sekiz duygu için ayrı ayrı Doğrulayıcı Faktör Analiz (DFA) yapılmıştır. DFA bulguları duygulara göre sırasıyla aşağıda sunulmuştur.

\subsubsection{Gurur Duygusu}

Gurur duygusu için tek faktörlü, dört faktörlü ve ikinci düzey faktör modelleri sınanmıştır. Gurur duygusuna ait güdüsel boyutun üçüncü maddesi GURM3 düşük faktör yükü nedeniyle modelden çıkarılmıştır. Yapılan analizde bilişsel boyutun maddelerinden üçünün (GURC2GURC3-GURC4) düşük OAV değerleri nedeniyle modelin dışında tutulmasına karar verilmiştir. Bilişsel boyuttaki bu maddeler modelden çıktıktan sonra modelin uyum indisleri ve OAV değerleri kabul edilebilir ve iyi uyum seviyesine gelmiştir. Gurur duygusu için her 3 model de doğrulanmıştır. Modellerin uyum indisleri incelendiğinde Gurur-tek faktörlü ölçüm modeli için RMSEA $=0,059, X^{2} / d f=2,05, \mathrm{CFI}=0.99, \mathrm{NFI}=0.98$ olarak, Gurur-dört faktörlü ölçüm modeli için RMSEA=0,023, $\mathrm{X}^{2} / d f=1,16, \mathrm{CFI}=0.99, \mathrm{NFI}=0.99$ olarak, İkinci düzey ölçüm modeli için RMSEA $=0,045, \mathrm{X}^{2} / d f=1,61, \mathrm{CFI}=0.99, \mathrm{NFI}=0.99$ olarak ortaya çıkmıştır.

Sınanan modellerin faktör yükleri, Cronbach Alpha, yapısal güvenirlik katsayısı ve OAV değerleri Tablo 2'de sunulmuştur.

Tablo 2. Gurur Duygusu için Güvenirlik ve Ortalama Açıklanan Varyans Değerleri

\begin{tabular}{|c|c|c|c|c|}
\hline & Standardize Edilmiş Katsayılar & Yak1 & ak Geçerlik & \\
\hline Madde & FY & $\alpha$ & OAV $\left(>.50^{a}\right)$ & YG $\left(>.70^{a}\right)$ \\
\hline \multicolumn{5}{|c|}{ Tek Faktörlü Model } \\
\hline GUR & & 0.80 & 0.45 & 0.80 \\
\hline GURC1 & 0.61 & & & \\
\hline GURM1 & 0.75 & & & \\
\hline GURM2 & 0.81 & & & \\
\hline GURP1 & 0.57 & & & \\
\hline GURA1 & 0.59 & & & \\
\hline \multicolumn{5}{|c|}{ Dört Faktörlü Model } \\
\hline \multicolumn{5}{|l|}{ Bilişsel } \\
\hline GURC1 & 0.88 & & 0.77 & 0.77 \\
\hline \multicolumn{5}{|l|}{ Güdüsel } \\
\hline GURM1 & 0.75 & 0.77 & 0.63 & 0.77 \\
\hline GURM2 & 0.83 & & & \\
\hline \multicolumn{5}{|c|}{ Fizyolojik } \\
\hline GURP1 & 0.90 & & 0.81 & 0.81 \\
\hline \multicolumn{5}{|c|}{ Duygulanımsal } \\
\hline GURA1 & 0.88 & & 0.77 & 0.77 \\
\hline
\end{tabular}

FY=Faktör Yükü; OAV=Ortalama Açıklanan Varyans; YG=Yapısal Güvenirlik katsayısı; $\alpha=$ Alpha Katsayısı. 
Tablo 2'de görüldüğü gibi, gurur duygusu 5 madde olarak ölçülmüştür. Daha iyi uyum indisi gösteren dört faktörlü modelin OAV değerlerinin 0.50 üstünde ve yapısal güvenirlik katsayılarının ise 0.60 üzerinde olduğu görülmüştür.

\subsubsection{Keyif Duygusu}

Keyif duygusu için tek faktörlü, dört faktörlü ve ikinci düzey faktör modelleri sinanmıştır. Keyif duygusunda, modele uyum sorunu gösterdiği için güdüsel KEYM1 maddesi çıkarılmıştır. Daha sonra model uyum indisleri incelendiğinde, bilişsel boyuttaki maddelerin OAV değerlerinin çok düşük olduğu tespit edilmiş ve modelden bilişsel maddelerin (KEYC1-KEYC2-KEYC3) çıkarılmasına karar verilmiştir. Buna göre üç faktörlü model sınanmıştır. Uyum indisleri incelendiğinde tek faktörlü ölçüm modeli için RMSEA $=0,050, \mathrm{X}^{2} / d f=1,76, \mathrm{CFI}=0.99, \mathrm{NFI}=0.99$ olarak; üç faktörlü ölçüm modeli için RMSEA $=0,085, \mathrm{X}^{2} / d f=3,20, \mathrm{CFI}=0.99, \mathrm{NFI}=0.99$ olarak, ikinci düzey ölçüm modeli için RMSEA=0.085, $\mathrm{X}^{2} / d f=3.20$, CFI=0.99, NFI=0.99 olarak ortaya çıkmıştır. Her üç model için GFI, CFI indekslerinin 0.95 'ten yüksek olması mükemmel uyum değerlerine sahip olduğunu göstermektedir. Sınanan modellerin faktör yükleri, Cronbach Alpha katsayısı, yapısal güvenirlik katsayısı ve OAV değerleri Tablo 3'de sunulmuştur.

Tablo 3. Keyif Duygusu Güvenirlik ve Ortalama Açıklanan Varyans Değerleri

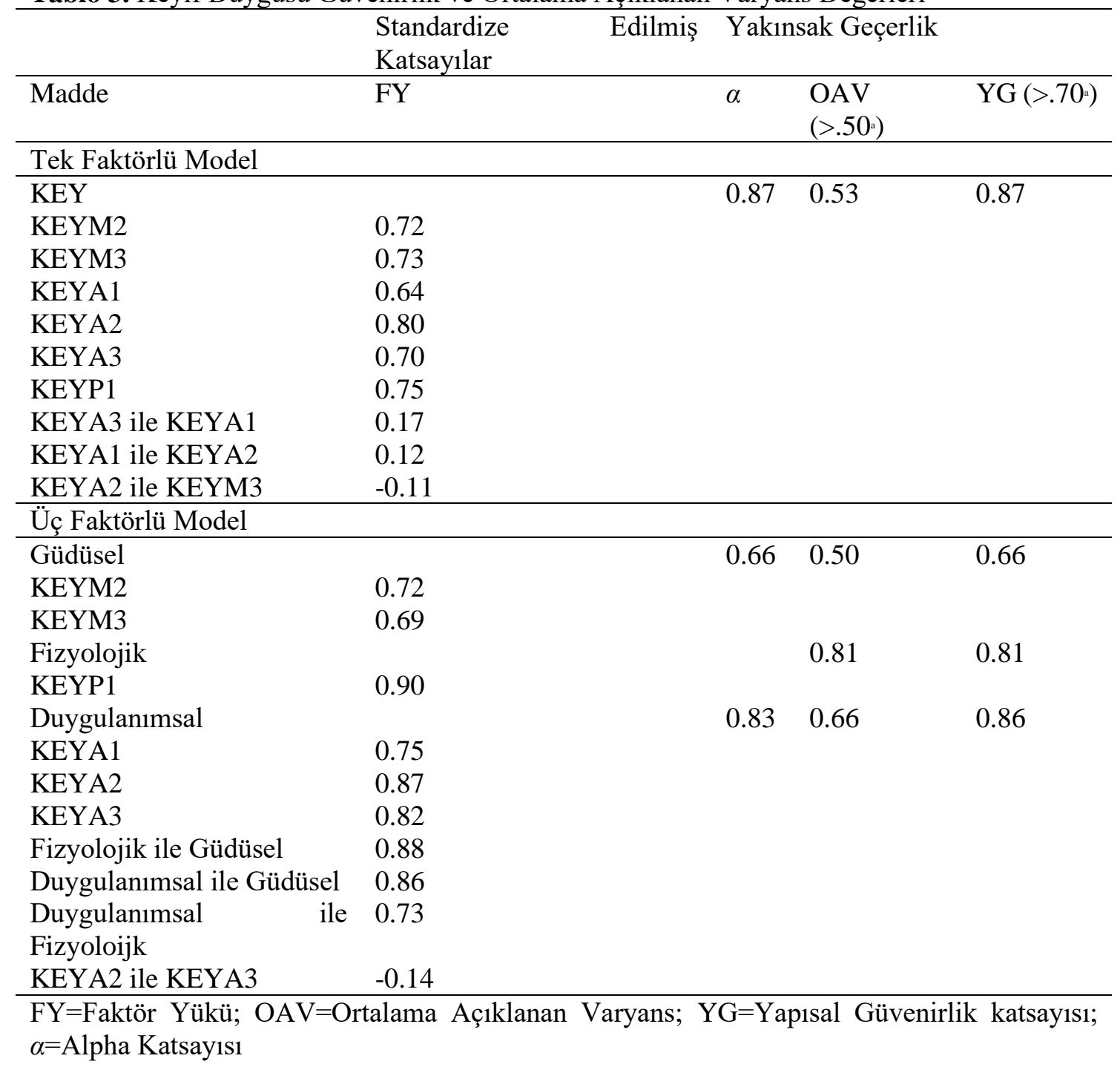


Tablo 3'te görüldüğü gibi keyif duygusu 6 madde ile ölçülmüştür. Sonuç olarak keyif duygusu, model uyum indisleri ele alındığında ikinci düzey ve üç faktörlü modelin yapısal olarak aynı olduğu ve geçerliğin sağlandığı görülmüştür.

\subsection{3. Öfke Duygusu}

Öfke duygusu için tek faktörlü, dört faktörlü ve ikinci düzey faktör modelleri sınanmıştır. Öfke duygusunda modele uyum sorunu gösterdiği için güdüsel maddelerden OFKM1 ve OFKM2 ile bilişsel maddelerden $\mathrm{OFKC} 2$ ve $\mathrm{OFKC} 3$ düşük $\mathrm{OAV}$ değerleri nedeniyle anketten çıkarılmıştır.

Modellerin uyum indisler incelendiğinde tek faktörlü ölçüm modeli için RMSEA $=0,047$, $\mathrm{X}^{2} / d f=1.69, \mathrm{CFI}=0.99, \mathrm{NFI}=0.98$ olarak; üç faktörlü ölçüm modeli için RMSEA=0,029, $\mathrm{X}^{2} / d f=$ 1,25, CFI=0.99, NFI=0.99 olarak; ikinci düzey ölçüm modeli için RMSEA=0,029, $\mathrm{X}^{2} / d f=1,25$, $\mathrm{CFI}=0.99, \mathrm{NFI}=0.99$ olarak ortaya çıkmıştır. Her üç model için GFI, CFI indekslerinin 0.95 'ten yüksek olması mükemmel uyum değerlerine sahip olduğunu göstermektedir. RMSEA'nın ise $0.05 \leq \mathrm{RMSEA} \leq .0 .08$ arasında olması kabul edilebilir uyum düzeyinde olduğunu işaret etmektedir (Hu ve Bentler, 1999). Bu sonuçlara göre üç faktör ve ikinci düzey ölçüm modelinin daha iyi sonuçlar verdiği söylenebilir. Sınanan modellerin faktör yükleri, Cronbach Alpha katsayısı, yapısal güvenirlik katsayısı ve OAV değerleri Tablo 4'te sunulmuştur.

Tablo 4 Öfke Duygusu Güvenirlik ve Ortalama Açıklanan Varyans Değerleri

\begin{tabular}{lllll}
\hline & $\begin{array}{l}\text { Standardize } \\
\text { Katsayılar }\end{array}$ & Edilmiş & Yakınsak Geçerlik & \\
\hline Madde & FY & $\alpha$ & $\begin{array}{l}\text { OAV } \\
\left(>.50^{2}\right)\end{array}$ & $\begin{array}{l}\text { YG } \\
\left(>.70^{2}\right)\end{array}$ \\
\hline Tek Faktörlü Model & & 0.82 & 0.51 & 0.84 \\
OFK & 0.52 & & & \\
OFKC1 & 0.80 & & & \\
OFKA1 & 0.71 & & & \\
OFKA2 & 0.76 & & & \\
OFKP1 & 0.76 & & & 0.79 \\
OFKP2 & & & 0.79 & \\
\hline Üç Faktörlü Model & & & \\
\hline Bilişsel & 0.89 & 0.75 & 0.60 & \\
OFKC1 & & & & \\
Duygulanımsal & 0.82 & & & \\
OFKA1 & 0.72 & 0.74 & 0.59 & \\
OFKA2 & & & & \\
Fizyolojik & 0.76 & & & \\
OFKP1 & 0.77 & & & \\
OFKP2 & 0.53 & & & \\
Duygulanımsal ile Bilişsel & 0.61 & & & \\
Fizyolojik ile Bilişsel & 0.94 & & & \\
Fizyolojik ile & & & & \\
Duygulanımsal & & & & \\
\hline
\end{tabular}

Sonuçlarda görüldüğ̈̈ gibi öfke duygusu beş madde ile ölçülmekte ve her üç modelin de doğrulandığı görülmektedir.

\subsubsection{Umut Duygusu}

Anketin özgün formunda umut duygusunda üç faktör yer almaktadır (bilişsel, duygulanımsal ve güdüsel). Yapılan doğrulayıcı faktör analizi sonucunda düşük OAV değerleri nedeniyle modelden bilişsel maddelerden UMUC1 ve UMUC2 çıkarılmıştır. Umut duygusu için modellerin uyum indisleri incelendiğinde tek faktörlü ölçüm modeli için RMSEA=0,072, $\mathrm{X}^{2} / d f=$ 2,60, CFI= 0.99, NFI=0.98 olarak; üç faktörlü ölçüm modeli için RMSEA=0,087, $\mathrm{X}^{2} / d f=3,30$, 
$\mathrm{CFI}=0.99, \mathrm{NFI}=0.98$ olarak; ikinci düzey ölçüm modeli için RMSEA=0,087, $\mathrm{X}^{2} / d f=3,30$, $\mathrm{CFI}=0.99, \mathrm{NFI}=0.98$ olarak ortaya çıkmıştır. Her üç model için GFI, CFI indekslerinin 0,95'ten yüksek olması mükemmel uyum değerlerine sahip olduğunu göstermektedir. Sınanan modellerin faktör yükleri, Cronbach Alpha katsayısı, yapısal güvenirlik katsayısı ve OAV değerleri Tablo 5 'te sunulmuştur.

Tablo 5. Umut Duygusu Güvenirlik ve Ortalama Açıklanan Varyans Değerleri

\begin{tabular}{|c|c|c|c|c|c|}
\hline \multirow{2}{*}{ Madde } & \multirow{2}{*}{$\begin{array}{l}\text { Standardize } \\
\text { Katsayilar } \\
\text { FY }\end{array}$} & \multirow[t]{2}{*}{ Edilmiş } & \multicolumn{3}{|c|}{ Yakınsak Geçerlik } \\
\hline & & & $\alpha$ & $\begin{array}{l}\text { OAV } \\
\left(>.50^{a}\right)\end{array}$ & $\begin{array}{l}\text { YG } \\
\left(>.70^{a}\right)\end{array}$ \\
\hline \multicolumn{6}{|l|}{ Tek Faktörlü Model } \\
\hline UMU & & & 0.86 & 0.46 & 0.86 \\
\hline UMUM1 & 0.72 & & & & \\
\hline UMUM2 & 0.75 & & & & \\
\hline UMUM3 & 0.72 & & & & \\
\hline UMUC3 & 0.68 & & & & \\
\hline UMUA1 & 0.68 & & & & \\
\hline UMUA2 & 0.72 & & & & \\
\hline \multicolumn{6}{|l|}{ Üç Faktörlü Model } \\
\hline Güdüsel & & & 0.78 & 0.53 & 0.77 \\
\hline UMUM1 & 0.72 & & & & \\
\hline UMUM2 & 0.75 & & & & \\
\hline UMUM3 & 0.72 & & & & \\
\hline Bilişsel & & & & 0.71 & 0.71 \\
\hline UMUC3 & 0.84 & & & & \\
\hline Duygulanımsal & & & 0.67 & 0.50 & 0.67 \\
\hline UMUA1 & 0.69 & & & & \\
\hline UMUA2 & 0.73 & & & & \\
\hline Bilişsel ile Güdüsel & 0.93 & & & & \\
\hline $\begin{array}{l}\text { Duygulanımsal ile } \\
\text { Güdüsel }\end{array}$ & 0.98 & & & & \\
\hline Duygulanımsal ile Bilişsel & 0.97 & & & & \\
\hline
\end{tabular}

Tablo 5'de görüldüğü gibi umut duygusu 6 madde olarak ölçülmüştür. Analiz sonuçlarına göre her üç modelin de doğrulandığı görülmektedir.

\subsubsection{Sıkılma Duygusu}

Modele uyum sorunu gösterdiği için güdüsel maddelerden SIKM3, duygulanımsal maddelerden SIKA1 ve SIKA2, fizyolojik maddelerden SIKP1 modelden çıkarılmıştır. Modellerin uyum indisleri incelendiğinde S1kılma-tek faktörlü ölçüm modeli için RMSEA=0,047, $\mathrm{X}^{2} / d f=1,66, \mathrm{CFI}=0.99, \mathrm{NFI}=0.99$ olarak, Sıkılma- üç faktörlü ölçüm modeli için RMSEA $=0,054, \mathrm{X}^{2} / d f=1,91, \mathrm{CFI}=0.99, \mathrm{NFI}=0.99$ olarak, İkinci düzey ölçüm modeli için RMSEA $=0,054, \mathrm{X}^{2} / d f=1,91, \mathrm{CFI}=0.99, \mathrm{NFI}=0.99$ olarak ortaya çıkmıştır. Sıkılma duygusu incelendiğinde tek faktör ve üç faktörlü modelin de mükemmel uyum sağladığ 1 görülmektedir. Sınanan modellerin faktör yükleri, Cronbach Alpha katsayısı, yapısal güvenirlik katsayısı ve OAV değerleri Tablo 6'da sunulmuştur. 
Tablo 6. S1kılma Duygusu Güvenirlik ve Ortalama Açılanan Varyans Değerleri

\begin{tabular}{|c|c|c|c|c|}
\hline & Standardize Edilmiş Katsayılar & Yak11 & sak Geçerlik & \\
\hline Madde & FY & $\alpha$ & $\mathrm{OAV}\left(>.50^{\circ}\right)$ & YG $\left(>.70^{2}\right)$ \\
\hline \multicolumn{5}{|l|}{ Tek Faktörlü Model } \\
\hline SIK & & 0.91 & 0.60 & 0.91 \\
\hline SIKM1 & 0.78 & & & \\
\hline SIKM2 & 0.72 & & & \\
\hline SIKC1 & 0.78 & & & \\
\hline SIKC2 & 0.84 & & & \\
\hline SIKP2 & 0.83 & & & \\
\hline SIKP3 & 0.76 & & & \\
\hline SIKP4 & 0.69 & & & \\
\hline \multicolumn{5}{|l|}{ Üç Faktörlü Model } \\
\hline Güdüsel & & 0.75 & 0.60 & 0.75 \\
\hline SIKM1 & 0.81 & & & \\
\hline SIKM2 & 0.74 & & & \\
\hline Bilișsel & & 0.80 & 0.67 & 0.80 \\
\hline SIKC1 & 0.78 & & & \\
\hline SIKC2 & 0.85 & & & \\
\hline Fizyolojik & & 0.81 & 0.59 & 0.81 \\
\hline SIKP2 & 0.84 & & & \\
\hline SIKP3 & 0.76 & & & \\
\hline SIKP4 & 0.69 & & & \\
\hline Bilișsel ile Güdüsel & 0.95 & & & \\
\hline Fizyolojik ile Güdüsel & 0.96 & & & \\
\hline Fizyolojik ile Bilişsel & 0.98 & & & \\
\hline
\end{tabular}

FY=Faktör Yükü; OAV=Ortalama Açıklana Varyans; YG=Yapısal Güvenirlik Katsayısı; $\alpha=$ Alpha Katsayıs 1

Sıkılma duygusu yedi madde ile ölçülmektedir. OAV, Cronbach Alpha ve yapısal güvenirlik katsayıları incelendiğinde sıkılma duygusu için tek faktörlü, üç faktörlü model ve ikinci düzey modelin de doğrulandığı görülmektedir.

\subsubsection{Utanma Duygusu}

Utanma duygusu için model analizleri gerçekleştirilmiş ve sonuçlar incelendiğinde modellerin hepsinde düşük RMSEA değerleri oluştuğu için madde atılma yoluna gidilmiştir. Güdüsel maddelerin UTAM1 ve UTAM2, bilişsel maddelerden ikisi UTAC3 ve UTAC4, fizyolojik maddelerden UTAP3 modelden çıkarılmıştır.

Modellerin uyum indisleri incelendiğinde Utanma-tek faktörlü ölçüm modeli için RMSEA $=0,084, X^{2} / d f=3,19, \mathrm{CFI}=0.99, \mathrm{NFI}=0.98$ olarak, Utanma-üç faktörlü ölçüm modeli için RMSEA=0,081, $\mathrm{X}^{2} / d f=3,00, \mathrm{CFI}=0.99, \mathrm{NFI}=0.99$ olarak, ikinci düzey ölçüm modeli için RMSEA $=0,081, \mathrm{X}^{2} / d f=3,00, \mathrm{CFI}=0,99, \mathrm{NFI}=0.99$ olarak ortaya çıkmıştır. Her üç model için GFI, CFI indekslerinin 0.95 'ten yüksek olması mükemmel uyum değerlerine sahip olduğunu göstermektedir. RMSEA'nın ise $0.05 \leq \mathrm{RMSEA} \leq .0 .08$ arasında olması kabul edilebilir uyum düzeyinde olduğundan hareketle her üç modelin de kabul edilebilir uyum gösterdiği söylenebilir. Sınanan modellerin faktör yükleri, Cronbach Alpha katsayısı, yapısal güvenirlik katsayısı ve OAV değerleri Tablo 7'de sunulmuştur. 
Tablo 7. Utanma Duygusu Güvenirlik ve Ortalama Aç1klanan Varyans Değerleri

\begin{tabular}{|c|c|c|c|c|}
\hline \multirow{2}{*}{ Madde } & \multirow{2}{*}{$\begin{array}{l}\text { Standardize } \\
\text { Katsayılar } \\
\text { FY }\end{array}$} & \multirow[t]{2}{*}{ Edilmiş } & Yakınsak Geçerlik & \multirow[b]{2}{*}{$\begin{array}{l}\text { YG } \\
\left(>.70^{2}\right)\end{array}$} \\
\hline & & & $\mathrm{OAV}\left(>.50^{a}\right)$ & \\
\hline \multicolumn{5}{|l|}{ Tek Faktörlü Model } \\
\hline UTA & & 0.88 & 0.56 & 0.88 \\
\hline UTAC1 & 0.73 & & & \\
\hline UTAC2 & 0.80 & & & \\
\hline UTAA1 & 0.52 & & & \\
\hline UTAA2 & 0.81 & & & \\
\hline UTAP1 & 0.77 & & & \\
\hline UTAP2 & 0.82 & & & \\
\hline \multicolumn{5}{|l|}{ Üç Faktörlü Model } \\
\hline Bilişsel & & 0.74 & 0.59 & 0.74 \\
\hline UTAC1 & 0.73 & & & \\
\hline UTAC2 & 0.80 & & & \\
\hline Fizyolojik & & 0.80 & 0.66 & 0.80 \\
\hline UTAP1 & 0.79 & & & \\
\hline UTAP2 & 0.84 & & & \\
\hline Duygulanımsal & & 0.64 & 0.53 & 0.68 \\
\hline UTAA1 & 0.55 & & & \\
\hline UTAA2 & 0.87 & & & \\
\hline Bilişsel ile Fizyoloijk & 0.98 & & & \\
\hline Bilişsel ile Duygulanımsal & 0.94 & & & \\
\hline $\begin{array}{l}\text { Duygulanımsal ve } \\
\text { Fizyolojik }\end{array}$ & 0.88 & & & \\
\hline
\end{tabular}

\subsubsection{Kaygı Duygusu}

Güdüsel maddelerden KAYM1 ve fizyolojik maddelerden KAYP1 düşük faktör yükleri sebebi ile modelden çıkarılmıştır. Daha sonra yapılan analizlerde bilişsel maddeler düşük OAV değeri verdiği için bu maddeler teker teker modelden çıkarılarak model yeniden incelenmiştir. Modele uyum sorunu gösterdiği için tüm bilişsel maddeler (KAYC1-KAYC2-KAYC3) modelden çıkarılmıştır.

Modellerin uyum indisleri incelendiğinde Kaygı-tek faktörlü ölçüm modeli için RMSEA =0,095, $\mathrm{X}^{2} / d f=3,76, \mathrm{CFI}=0.98, \mathrm{NFI}=0.97$ olarak, Kayg1-üç faktörlü ölçüm modeli için RMSEA $=0,072, \mathrm{X}^{2} / d f=2,59, \mathrm{CFI}=0.99, \mathrm{NFI}=0.98$ olarak, ikinci düzey ölçüm modeli için RMSEA $=0,072, \mathrm{X}^{2} / d f=2,59, \mathrm{CFI}=0.99, \mathrm{NFI}=0.98$ olarak ortaya çıkmıştır. Her üç model için GFI, CFI indekslerinin 0.95 'ten yüksek olması mükemmel uyum değerlerine sahip olduğunu göstermektedir. S1kılma duygusu incelendiğinde tek faktör ve üç faktörlü modelin de doğrulandığı görülmektedir. Sınanan modellerin faktör yükleri, Cronbach Alpha katsayısı, yapısal güvenirlik katsayısı ve OAV değerleri Tablo 8'de sunulmuştur. 
Tablo 8. Kayg1 Duygusu Güvenirlik ve Ortalama Açıklanan Varyans Değerleri

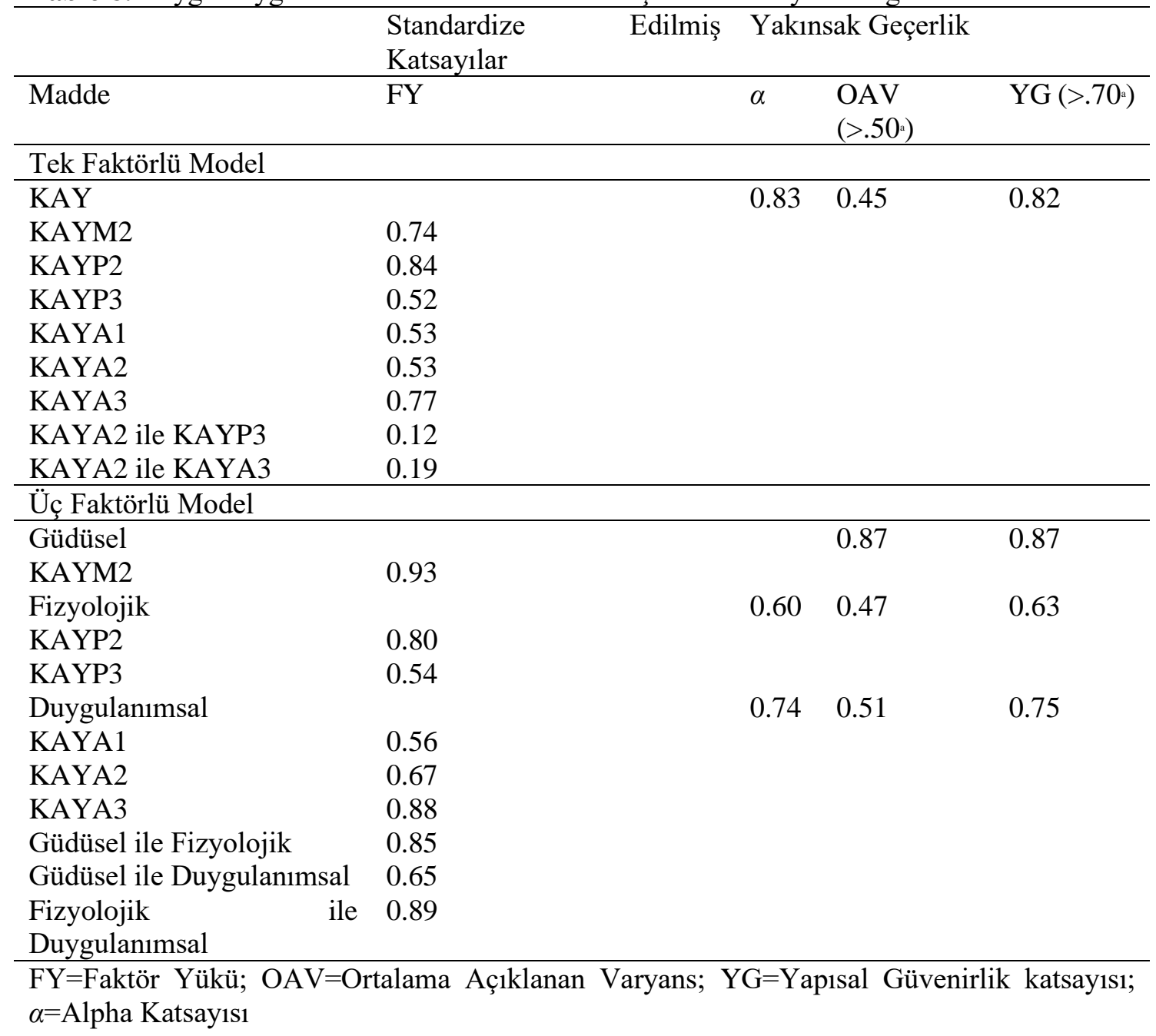

Kayg1 duygusu altı madde ile ölçülmektedir. Kaygı duygusu incelendiğinde üç faktörlü modelin ve ikinci düzey modelin doğrulandığ 1 gözükmektedir. Fakat fizyolojik bileşenin OAV değerinin 0.47 olduğu ve 0,50 altında kaldığı görülmüştür. Bununla ilgili olarak Lam (2012), Fornell ve Larcker (1981) çalışmasına atıfta bulunarak ortalama açıklanan varyans değeri 0.50 nin altında olduğu durumlarda yapının birleşim güvenirliğinin sağlanması halinde yakınsama geçerliğinin sağlandığını kabul edebileceğini belirtmiştir. Bu durumda 0.47 değerinin 0.50 'ye yakın olması ve kuramsal altyapıya uygun olması nedeniyle yapının yakınsama geçerliğinin sağlandığ 1 ifade edilebilir.

\subsubsection{Umutsuzluk Duygusu}

Umutsuzluk duygusu için gerçekleştirilen analizler sonucunda düşük faktör yükü nedeniyle güdüsel maddelerden UMSM1 modelden çıkarılmıştır. Düşük OAV değerleri nedeni ile güdüsel maddelerden UMSM3, bilişsel maddelerden UMSC2 ve UMSC3, fizyolojik maddelerden UMSP2 modelden çıkarılmıştır. Bununla birlikte tek faktörlü modelin doğrulandığ1 ve diğer iki modelin doğrulanmadığ sonucuna ulaşılmıştır. Tek faktörlü modelin RMSEA=0,088, $\mathrm{X}^{2} / d f=$ $3,36, \mathrm{CFI}=0.98$ ve $\mathrm{NFI}=0.97$ olarak belirlenirken RMSEA değerinin kabul edilebilir ve uyum indislerinin mükemmel olduğu belirlenmiştir. Tek faktörlü modelin, faktör yükleri, Cronbach Alpha katsayısı, yapısal güvenirlik katsayısı ve OAV değerleri Tablo 9'da sunulmuştur. 


\begin{tabular}{lllllllll}
\hline 1 & 2 & 3 & 4 & 5 & 6 & 7 & 8 \\
\hline
\end{tabular}

(1) Kayg1

(2)Utanma $\quad .723^{* *}$

(3) Sikilma $\quad .430^{* *} \quad .436^{* *}$

(4) Öfke $\quad .439^{* *} \quad .409^{* *} \quad .591^{* * *}$

(5) Umutsuzluk $\quad .635^{* *} \quad .526^{* *} \quad .612^{* *} \quad .595^{* *}$

$\begin{array}{llllll}\text { (6) Keyif } \quad-.315^{* *} & -.164^{* *} & -.448^{* *} & -.281^{* *} & -.346^{* *}\end{array}$

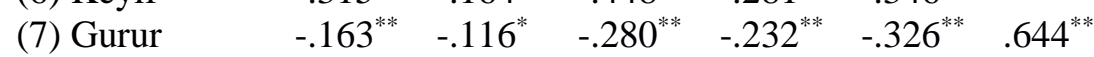

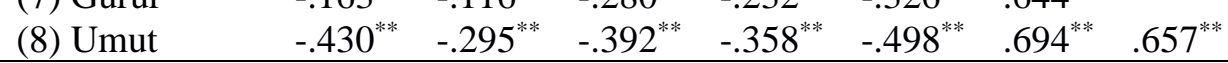

$* \mathrm{p}<.05$

$* * \mathrm{p}<.01$

Tablo 11'e göre, gurur ve umut duygusu arasında pozitif bir ilişki bulunmuştur. Ayrıca, kayg1, sıkılma, öfke, umutsuzluk ve utanma duygusu da birbirleri ile pozitif ilişkili olarak belirlenmiştir. Buradan hareketle pozitif duyguların birbiriyle pozitif ve negatif duygularla da negatif ilişkili olduğu görülebilmektedir.

$\mathrm{Bu}$ ilişkiler içinde, pozitif duygulardan umut ve keyif duygusunun, negatif duygulardan kayg1 ve utanma duygusunun yüksek düzeyde ilişkili olduğu görülebilmektedir. Negatif harekete geçirici duygular olan kaygı ve utanma duygusunun aynı zamanda sonuç odaklı duygular olması yüksek düzeyde ilişkili olmalarına sebep olarak gösterilebilir. Umut ve keyif duygusunun yüksek düzeyde ilişkili olmasının bir sebebi pozitif harekete geçirici duygular olmasından kaynaklanabilir. Öte yandan, keyif duygusunun uygulama odakl1, umut duygusunun ise sonuç odaklı bir duygu olması nedeniyle bu noktada farklı etkilerin varlığından söz edilebilir. Anketin kısa formu için yapılan Pearson korelasyon katsayıları Tablo 12'de verilmiştir.

Tablo 12. Kisa Form Duygu Korelasyon Tablosu

\begin{tabular}{lcccccccc}
\hline & 1 & 2 & 3 & 4 & 5 & 6 & 7 & 8 \\
\hline Gurur (1) & & & & & & & \\
Keyif (2) & $.675^{* *}$ & & & & & & \\
Öfke (3) & $-.213^{* *}$ & $-.211^{* *}$ & & & & & \\
Umut (4) & $.658^{* *}$ & $.706^{* *}$ & $-.321^{* *}$ & & & & \\
Kayg1 (5) & $-.251^{* *}$ & $-.290^{* *}$ & $.357^{* *}$ & $-.282^{* *}$ & & & \\
Utanma (6) & $-.193^{* *}$ & $-.120^{*}$ & $.308^{* *}$ & $-.194^{* *}$ & $.725^{* *}$ & & \\
Sik1lma (7) & $-.370^{* *}$ & $-.388^{* *}$ & $.521^{* *}$ & $-.386^{* *}$ & $.436^{* *}$ & $.363^{* *}$ & \\
Umutsuzluk & $-.352^{* * *}$ & $-.327^{* *}$ & $.544^{* *}$ & $-.427^{* *}$ & $.493^{* *}$ & $.400^{* *}$ & $.558^{* *}$ & \\
$(8)$ & & & & & & & \\
\hline${ }^{*} \mathrm{p}<0.01$ & & & & & & & & \\
${ }^{* *} \mathrm{p}<0.05$ & & & & & & &
\end{tabular}

Tablo 12'ye göre kısa form için hesaplanan korelasyon katsayılarının de uzun form ile tutarlılık gösterdiği görülmektedir. Tablodaki korelasyonlar dikkate alındığında pozitif duygulardan gurur, umut ve keyif duygusunun yüksek düzeyde ilişkili olduğu görülmüştür. Negatif duygulardan ise kaygı ve utanma arasında yüksek düzeyde ilişki gözlemlenmiştir. 


\section{TARTIŞMA, SONUÇ VE ÖNERILLER}

Bu çalışmada, Pekrun, Goetz ve Perry (2005) tarafindan geliştirilen ve Can, Emmioğlu Sarıkaya ve Bardakçı (2020) tarafından lise öğrencileri için Türkçeye uyarlaması yapılan Başarı Duyguları Anketinin, dersle ilgili duygular bölümünün öğretmen adayları için geçerleme çalışması yapılmış ve bu ölçme aracının kısa formu oluşturularak psikometrik özellikleri incelenmiştir. Ölçme aracında yer alan maddelerin başarım (performans) temelinde olması ve aracın içeriğini de daha uygun yansıttığı gerekçesiyle bu çalışmada ölçme aracına "başarımla ilgili duygular" adı verilmiştir. Kısa formda da özgün anketteki gibi başarımla ilgili duygular bilişsel, güdüsel, fizyolojik ve duygulanımsal bileşenler temsil edilecek şekilde geliştirildiğinden kısa formdan alınan toplam puan, duygularla ilgili olumlu ya da olumsuz bir anlam ifade etmemektedir.

Duygu ile yapılan Türkçeye uyarlama çalışmaları incelendiğinde alanyazında, "Başarı Duygusu ölçeği-ilkokul" (Haciömeroğlu, Bilgen ve Tabuk, 2013) , "Öğretmen Adayları İçin Öğretmen Duygu Ölçeği-Matematik" (Hacıömeroğlu, 2020) ve "Başarı Duyguları Anketi" (Can, Emmioğlu Sarıkaya ve Bardakçı, 2020) olduğu görülmüştür. Hacıömeroğlu, Bilgen ve Tabuk'un (2013) çalışmalarında ilkokul öğrencileri için kaygı, sıkılma ve keyif duygusu ele alınırken, Can, Emmioğlu Sarıkaya ve Bardakçı'nın (2020) çalışmalarında lise öğrencileri için keyif, umut, gurur, sıkılma, rahatlama, öfke, kaygı, utanma ve umutsuzluk duyguları yer almıştır. Bu çalışmalar incelendiğinde öğretmen adayları için geçerleme çalışması yapılmış bir ölçme aracı bulunmadığı belirlenmiştir. Hacıömeroğlu'nun (2020) öğretmen adayları için kullandığı ölçek öğretmenler için geliştirilmiş ve sadece üç duygu (keyif, öfke ve kaygi) incelenmiştir. İlgili çalışmaların sonuçları incelendiğinde bir çalışmada (Can, Emmioğlu Sarıkaya ve Bardakçı, 2020) uyarlaması yapılan ölçeğin özgün ölçekle genel olarak benzerlik taşıdığı ifade edilirken; diğer iki çalışmada (Hacıömeroğlu, 2020; Hacıömeroğlu, Bilgen ve Tabuk, 2013) özgün ölçekteki faktör yapıları ile uyarlaması yapılan ölçeklerdeki yapıların aynı olduğu belirtilmiştir.

Geçerleme çalışması yapılan anketin (Can, Emmioğlu Sarıkaya ve Bardakçı, 2020) özgün formunda dersle ilgili duygular bölümü; ders öncesi, ders esnası ve ders sonrası olmak üzere toplamda sekiz duygu ve 80 madde içermektedir. Bu duyguların modüler olarak kullanılabildiği gibi bir bütün olarak da kullanılabildiği dile getirilmektedir (Pekrun, Goetz ve Perry, 2005). Duyguların birden çok boyutu olduğu, duygulanımsal, bilişsel, güdüsel ve fizyolojik olarak dört boyuttan oluştuğu ileri sürülmektedir (Pekrun ve diğerleri, 2011). Bu nedenle bu araştırmada her bir duygu için tek faktörlü ve dört faktörlü modeller sinanmıştır. Geçerleme çalışması kapsamında yapı geçerliği için doğrulayıcı faktör analizi yapılmış, OAV ve güvenirlik değerleri incelenmiştir. Geçerleme çalışmasında alanyazındaki faktör yükü 0.40 ve altında olan maddelerin atılması (Hair, Ringle ve Sarstedt, 2011) ölçütüne göre göstergelerin silinmesinin yakınsak güvenilirlikte önerilen eşik değerin (.60 ve üstü) üzerinde bir artışa yol açması nedeniyle de faktör yükü .50 altında olan maddeler anketten çıkarılmıştır.

Gurur ve sıkılma duygularında duygulanımsal; keyif ve kaygı duygularında bilişsel; umutsuzluk, öfke ve utanma duygularında güdüsel boyut, belirtilen ölçütleri karşılamaması nedeniyle modelden çıkarılmıştır. Umut duygusunda ise anketin orjinalinde fizyolojik boyuta ilişkin bir madde olmaması nedeniyle sözü edilen duyguların tamamı üç faktörlü yapıyla doğrulanmıştır. Bununla birlikte umutsuzluk duygusunda dört faktörlü yapı ve tek faktörlü yapı sınandığında tek faktörlü yapının OAV değerleri, yapısal güvenilirlik ve uyum indisleri açısından daha uygun değerler vermesi nedeniyle umutsuzluk duygusu tek faktör olarak doğrulanmıştır. Umutsuzluk duygusu haricinde üç faktörlü yapıyla doğrulanmış yedi duygu için ikinci düzey faktör analizi gerçekleştirilmiş ve elde edilen uyum değerlerinin kabul edilebilir ve iyi uyum sınırları içerisinde olduğu görülmüştür. Anketin güvenirlik çalışması için Cronbach Alpha ve yapısal güvenirlik katsayısı (CR) incelenmiştir. Cronbach Alpha değerleri doğrulanan üç faktörlü duygu modelleri için 0.60 ve 0.83 arasında değişirken tek faktörlü umutsuzluk 
duygusu için 0.79 olarak belirlenmiştir. Yapısal güvenirlik katsayısı üç faktörlü duygu modelleri için 0.63 ve 0.87 arasında, tek faktörlü umutsuzluk duygusunda 0.79 olarak tespit edilmiştir. $\mathrm{Bu}$ sonuçlara göre anketin geçerlik ve güvenirliğine kanıt sağlandığı söylenebilir.

Öz bildirime dayalı ölçme araçlarının kısa form çalışmalarına bir eğilim olduğu ifade edilmektedir (Ziegler, Kempen ve Kruyen, 2014). Özellikle duygu ile ilgili çalışmalarda, kısa formlar kullanılarak daha az madde sayısı ile tek faktörlü yapıların kullanıldığı görülmektedir. Örneğin, Peixoto, Mata, Monteiro, Sanches ve Pekrun, (2015) ergenlik çağındaki gençler için tasarladıkları BİDA'nın kısa formunda her duygu için sadece en yüksek faktör yüklerini gösteren dört maddeyi alarak bir form oluşturmuşlardır. Nitekim, duyguları değerlendirmeye yönelik kısa ölçme araçlarının zaman kısıtlamaları katı olduğunda daha avantajlı olduğu ifade edilmektedir (Raccanello ve diğerleri, 2021). Ayrıca duyguları belirlemek üzere geliştirilmiş ölçeklerde madde sayısının fazla olması daha uzun yanıtlama sürelerini gerektirmektedir. Dolayısıyla, duyguları ölçmek üzere tasarlanmış bir ölçme aracının öğrenciler tarafından yanıtlama sürecinde duygular değişiklik gösterebilmektedir. Bu bağlamda, alanyazında çevrimiçi öğrenme ortamlarında dersle ilgili duygular kapsamında herhangi bir kısa formun bulunmaması nedeni ile en yüksek faktör yükünü veren maddelerin seçilmesi gözetilerek kısa form oluşturulmuştur. Bu çalışmada oluşturulan kısa formun uyum indisleri RMSEA 0.070 ve CFI: 0.96 ve NFI: 0.94 olarak belirlenmiş ve bu uyum indisleri iyi ve mükemmel olarak değerlendirilmiştir. Cronbach Alpha değeri 0.75, OAV değerleri gurur için 0.47, öfke için 0.49, umut için 0.51 , keyif için 0.58 , kaygı için 0.59 , utanma için 0.66 , sıkılma için 0.68 , umutsuzluk için 0.48 olarak belirlenmiştir. Lam (2012), Fornell ve Larcker (1981) çalışmasına atıfta bulunarak ortalama açıklanan varyans değeri 0.50 nin altında olduğu durumlarda yapısal güvenirliğinin sağlanması halinde yakınsama geçerliğinin sağlandığının kabul edilebileceğini belirtmiştir. Kısa formun yapısal güvenirlik katsayılarının 0.73 ve 0.86 arasında olması ve elde edilen diğer bulgular, yakınsama geçerliğinin sağladığına yönelik yeterli kanıtları sunmaktadır. Sonuç olarak bu çalışmada BİDA'nın dersle ilgili duygular bölümünün, öğretmen adayları için geçerleme çalışması yapılmış; geçerlik ve güvenirliği kanıtlanmış 24 maddeden oluşan BIDA kisa formu ortaya konulmuştur.

Duyguların öğrenme ve öğretim bağlamında önemini ortaya koyan araştırmalardan hareketle, bu çalışmanın çevrimiçi öğrenme ortamları ve öğretmen yetiştirme programları için veri toplama sürecinde katkı sağlayabileceği ileri sürülebilir.

\section{KATKI VE TEȘEKKÜR}

Değerli görüşleri ve katkıları için Prof. Dr. Halil Yurdugül'e teşekkür ederiz.

\section{KAYNAKÇA}

Can, Y. , Sarıkaya, E. E. ve Bardakçı, S . (2020). Başarı duyguları anketinin Türk kültürüne uyarlanmas1. Kastamonu Eğitim Dergisi, 28(2), 673-693. Doi: 10.24106/kefdergi.697110.

D'Errico, F., Paciello, M., \& Cerniglia, L. (2016). When emotions enhance students' engagement in e-learning processes. Journal of e-Learning and Knowledge Society, 12(4), 9-23.

Fornell, C., \& Larcker, D. F. (1981). Evaluating structural equation models with unobservable variables and measurement error. Journal of marketing research, 18(1), 39-50.

Fried, L. (2011). Teaching teachers about emotion regulation in the classroom. Australian Journal of Teacher Education (Online), 36(3), 117-127. 
Gefen, D., Straub, D. W., \& Boudreau, M. C. (2000). Structural equation modeling and regressing: guidelines for research practice. Communications of the Association of Information Systems, 4(7), 1-70.

Hacı̈̈meroğlu, G. (2020). Öğretmen adayları için öğretmen duygu ölçeği-Matematik Türkçe formu: Geçerlik ve güvenilirlik çalışması. Sakarya Üniversitesi Eğitim Fakültesi Dergisi, 20(2), 133-147.

Hacıömeroğlu, G., Bilgen, S. ve Tabuk, M. (2013). Başarı duygusu ölçeği-ilkokul'un Türkçe'ye uyarlama çalışması. Eğitim Bilimleri Dergisi, 38, 85-96. Doi:10.15285/EBD.2013385568.

Hair, J. F., Anderson, R. E., Tatham, R. L., \& Black, W. C. (1998). Multivariate data analysis (5th Ed.). Upper Saddle River, NJ: Prentice Hall.

Hair, J. F. , Ringle, C M., \& Sarstedt, M. (2011) PLS-SEM: Indeed a silver bullet. Journal of Marketing Theory and Practice, 19(2), 139-152, Doi: 10.2753/ MTP1069-6679190202

Hair, J. F., Hult, G. T. M., Ringle, C. M., \& Sarstedt, M. (2017). A primer on partial least squares structural equation modeling (PLS-SEM). Thousand Oaks, CA

Hambleton, R. K., \& Patsula, L. (1999). Increasing the validity of adapted tests: Myths to be avoided and guidelines for improving test adaptation practices. Journal of Applied Testing Technology, 1(1), 1-30.

Harley, J. M., Lajoie, S. P., Tressel, T., \& Jarrell, A. (2018). Fostering positive emotions and history knowledge with location-based augmented reality and tour-guide prompts. Learning and Instruction, 70, 101163.

Harrington, D. (2009). Confirmatory factor analysis. Oxford University Press.

Hayat, A. A., Shateri, K., Amini, M., \& Shokrpour, N. (2020). Relationships between academicself-efficacy, learning-related emotions, and metacognitive learning strategies with academic performance in medical students: A structural equation model. $B M C$ MedicalEducation, 20(1), 1-11.

Hilliard, J., Kear, K., Donelan, H., \& Heaney, C. (2020). Students' experiences of anxiety in an assessed, online, collaborative project. Computers \& Education, 143, 103675.

Hu, L. T., \& Bentler, P. M. (1999). Cutoff criteria for fit indexes in covariance structure analysis: Conventional criteria versus new alternatives. Structural Equation Modeling: A Multidisciplinary Journal, 6(1), 1-55.

Immordino Yang, M. H., \& Damasio, A. (2007). We feel, therefore we learn: The relevance of affective and social neuroscience to education. In Jossey-Bass reader on the brain and learning (pp. 183-198). San Francisco: Jossey-Bass Reader on the Brain and Learning (pp. 183-198). San Francisco: Jossey-Bass.

Kline, R. B. (2005). Principles and practice of structural equation modeling (2nd Ed.). New York, NY: Guilford Press.

Krithika, L., \& Lakshmi Priya, G. (2016). Student emotion recognition system (SERS) for elearning improvement based on learner concentration metric. Procedia Computer Science, 85, 767-776. https://doi.org/10.1016/J.PROCS.2016.05.264

Lajoie, S. P., Pekrun, R., Azevedo, R., \& Leighton, J. P. (2019). Understanding and measuring emotions in technology-rich learning environments. Learning and Instruction, 101272.

Lam, L. W. (2012). Impact of competitiveness on salespeople's commitment and performance. Journal of Business Research, 65(9), 1328-1334. 
Marchand, G. C., \& Gutierrez, A. P. (2012). The role of emotion in the learning process: Comparisons between online and face-to-face learning settings. The Internet and Higher Education, 15(3), 150-160.

Mardia, K. V. (1970). Measures of multivariate skewness and kurtosis with applications. Biometrika, 57(3), 519-530.

Obergriesser, S., \& Stoeger, H. (2020). Students' emotions of enjoyment and boredom and their use of cognitive learning strategies-How do they affect one another?. Learning and Instruction, 66, 101285.

Park, T., \& Lim, C. (2019). Design principles for improving emotional affordances in an online learning environment. Asia Pacific Education Review, 20(1), 53-67.

Parkinson, B., \& Totterdell, P. (1999). Classifying affect-regulation strategies. Cognition \& Emotion, 13(3), 277-303.

Peixoto, F., Mata, L., Monteiro, V., Sanches, C., \& Pekrun, R. (2015). The achievement emotions questionnaire: Validation for pre-adolescent students. European Journal of Developmental Psychology, 12(4), 472-481.

Peklaj, C., \& Pečjak, S. (2011). Emotions, motivation and self-regulation in boys' and girls' learning mathematics. Horizons of Psychology, 20(3), 33-58.

Pekrun, R. (1992). The impact of emotions on learning and achievement: Towards a theory of cognitive/motivational mediators. Applied Psychology, 41(4), 359-376.

Pekrun, R. (2000). A social cognitive, control-value theory of achievement emotions. In J. Heckhausen (Ed.), Motivational psychology of human development (pp. 143-163). Oxford, England: Elsevier.

Pekrun, R. (2006). The control-value theory of achievement emotions: Assumptions, corollaries, and implications for educational research and practice. Educational Psychology Review, $18(4), 315-341$.

Pekrun, R. (2019). Inquiry on emotions in higher education: progress and open problems. Studies in Higher Education, 44(10), 1806-1811.

Pekrun, R., Frenzel, A. C., Goetz, T., \& Perry, R. P. (2007). The control-value theory of achievement emotions: An integrative approach to emotions in education. In P. A. Schutz \& R. Pekrun (Ed.), Emotion in education (pp. 13-36). San Diego, CA: Academic Press.

Pekrun, R., Goetz, T., Frenzel, A. C., Barchfeld, P., \& Perry, R. P. (2011). Measuring emotions in students' learning and performance: The Achievement Emotions Questionnaire (AEQ). Contemporary Educational Psychology, 36(1), 36-48.

Pekrun, R., Goetz, T., \& Perry, R. P. (2005). Achievement emotions questionnaire (AEQ). User's manual. (Unpublished Manuscrip). University of Munich. Munich.

Pekrun, R., \& Perry, R. P. (2014). Control-value theory of achievement emotions. In R. Pekrun \& L. Linnenbring Garcia (Ed.), International handbook of emotions in education (pp. 130151). Routledge.

Pekrun, R., \& Stephens, E. J. (2010). Achievement emotions: A control-value approach. Social and Personality Psychology Compass, 4(4), 238-255.

Raccanello, D., Brondino, M., Crescentini, A., Castelli, L., \& Calvo, S. (2021): A brief measure for school-related achievement emotions: The achievement Emotions Adjective List (AEAL) for secondary students. European Journal of Developmental Psychology, 1-19. Doi: 10.1080/17405629.2021.1898940 
Raykov, T., \& Marcoulides, G. A. (2008). An introduction to applied nultivariate analysis. New York, NY: Taylor and Francis.

Regan, K., Evmenova, A., Baker, P., Jerome, M. K., Spencer, V., Lawson, H., et. al. (2012). Experiences of instructors in online learning environments: Identifying and regulating emotions. The Internet and Higher Education, 15(3), 204-212.

Rienties, B., \& Rivers, B. A. (2014). Measuring and understanding learner emotions: Evidence and prospects. Learning Analytics Review, 1, 1-28.

Sanches, C., Monteiro, V., Mata, L., Santos, N., \& Gomes, M. (2020). Psychometric properties of the Portuguese version of the achievement emotions questionnaire for elementary school. Análise Psicológica, 38(1), 127-139.

Schrader, C., \& Kalyuga, S. (2020). Linking students' emotions to engagement and writing performance when learning Japanese letters with a pen-based tablet: An investigation based on individual pen pressure parameters. International Journal of Human-Computer Studies, $135,102374$.

Stephan, M., Gläser Zikuda, M., \& Markus, S. (2019). Students' achievement emotions and online learning in teacher education. In Frontiers in education (Vol. 4, p. 109). Frontiers.

Wosnitza, M., \& Volet, S. (2005). Origin, direction and impact of emotions in social online learning. Learning and instruction, 15(5), 449-464.

You, J. W., \& Kang, M. (2014). The role of academic emotions in the relationship between perceived academic control and self-regulated learning in online learning. Computers \& Education, 77, 125-133.

Ziegler, M., Kemper, C. J., \& Kruyen, P. (2014). Short scales-Five misunderstandings and ways to overcome them. Journal of Individual Differences, 35, 185-189.

\section{EKLER}

Ek 1: BİDA Uzun Form

\begin{tabular}{lllllll}
\hline Ders Öncesi & Maddeler & (1) & (2) & (3) & (4) & (5) \\
\hline
\end{tabular}

Derse girmek için sabırsızlanırım.

KEYA1

Konuyu anlayacağıma dair kendime güven

UMUM1

duymam beni derse motive ediyor.

Derste kendime güveniyorum.

UMUA1

Derse karşı umut doluyum.

UMUA2

Derse girmeden önce bile konuyu

UMSC1

anlamayacağım gerçeğini kabulleniyorum.

Kendime olan güvenim derse hazırlanmam

UMUM2

konusunda beni motive ediyor.

$\mathrm{Bu}$ dersi düşünmek beni umutsuz

hissettiriyor.

UMSA1 
Başarılı olacağım ümidi daha fazla gayret

UMUM3

göstermemi sağliyor.

Dersi düşünmek beni huzursuz ediyor.

KAYA1

Umudumu kaybettiğim için derse girmeye

UMSM2

enerjim yok.

Derste Korkuyorum.

KAYA2

Derste olmaktan keyif alıyorum.

KEYA2

\section{Ders Esnası}

Ders çok sıkıcı olduğu için dersten çıkıp

SIKM1

gidesim geliyor.

Derste bir şey söylediğim zaman yüzüm

UTAP1

kızarmış gibi hissediyorum.

Derste kendimi sinirli hissediyorum

OFKA1

Zaman geçmek bilmediğinden s1k s1k saatime SIKM2 bakarım.

Dersi takip edebileceğim için kendimle gurur GURC1 duyuyorum.

Konuyu anlamadığım için kendimi dersten

UMSP1 kopmuş ve pes etmiş hissediyorum.

Dersten aldığım keyif beni derse katılmaya teşvik ediyor.

KEYM2

Derste bir şey söylediğimde kendimi aptalca bir şey yapmış gibi hissediyorum.

Derste geriliyorum.

KAYP2

Konuyu anladığım için kendime

UMUC3 güveniyorum.

Öfkemin içimde kabardığını hissediyorum.

OFKP1

Ders öylesine heyecan verici ki saatlerce

KEYM3 sinıfta oturup öğretmeni dinleyebilirim.

O kadar sıkıldım ki uyanık kalmakta çok zorlaniyorum.

Mahcup hissediyorum.

Dersin kalitesizliğini düşündüğümde

OFKC1 öfkeleniyorum. 
Derste çok sıkıldığı̆m için esnemeye

SIKP3

başliyorum.

Derse önemli bir katkı yaptığımda daha da

GURM1

motive oluyorum.

Kendimi iyi ifade edemediğim için

UTAC2

utaniyorum.

Umutsuz hissediyorum.

UMSA2

Derse katılmaktan o kadar zevk alıyorum ki

KEYP1

bu derse katılmak bana enerji veriyor.

Derste gerginim.

KAYA3

$\mathrm{Bu}$ ders beni sıkıyor.

SIKC1

Utandığım için kendimi gergin ve çekingen

UTAP2

hissediyorum.

Öfkemden ötürü derste huzursuz oluyorum.

OFKP2

Yanlış bir şey söylemekten korktuğum için

KAYM2

derste hiçbir şey söylememeyi tercih

ediyorum.

Ders esnasında üzerime bir ağırlık çöküyor, kendimi sırama gömülüyormuşum gibi

hissediyorum.

Derste utanmış hissediyorum.

UTAA2

Derste başarılı olduğum zaman kalbim

GURP1 gururla çarpiyor.

Sıkıldığım için kafam başka yerlerde.

SIKC2

Derste önemli bir șeyi anlamadığımda kalbim KAYP3 hızla çarpıyor.

\section{Ders Sonrası}

Bir ders bittikten sonra hevesle diğer dersi KEYA3 beklerim.

Kendimle gurur duyuyorum.

GURA1

Öfkeliyim.

OFKA2

Derste gösterdiğim başarılardan gurur GURM2 duyduğum için derse devam etmeye motive oluyorum.

1: Kesinlikle katılmıyorum; 2: Kismen katılmıyorum; 3: Kararsızım; 4: Kısmen katılıyorum 5: Kesinlikle katılıyorum 


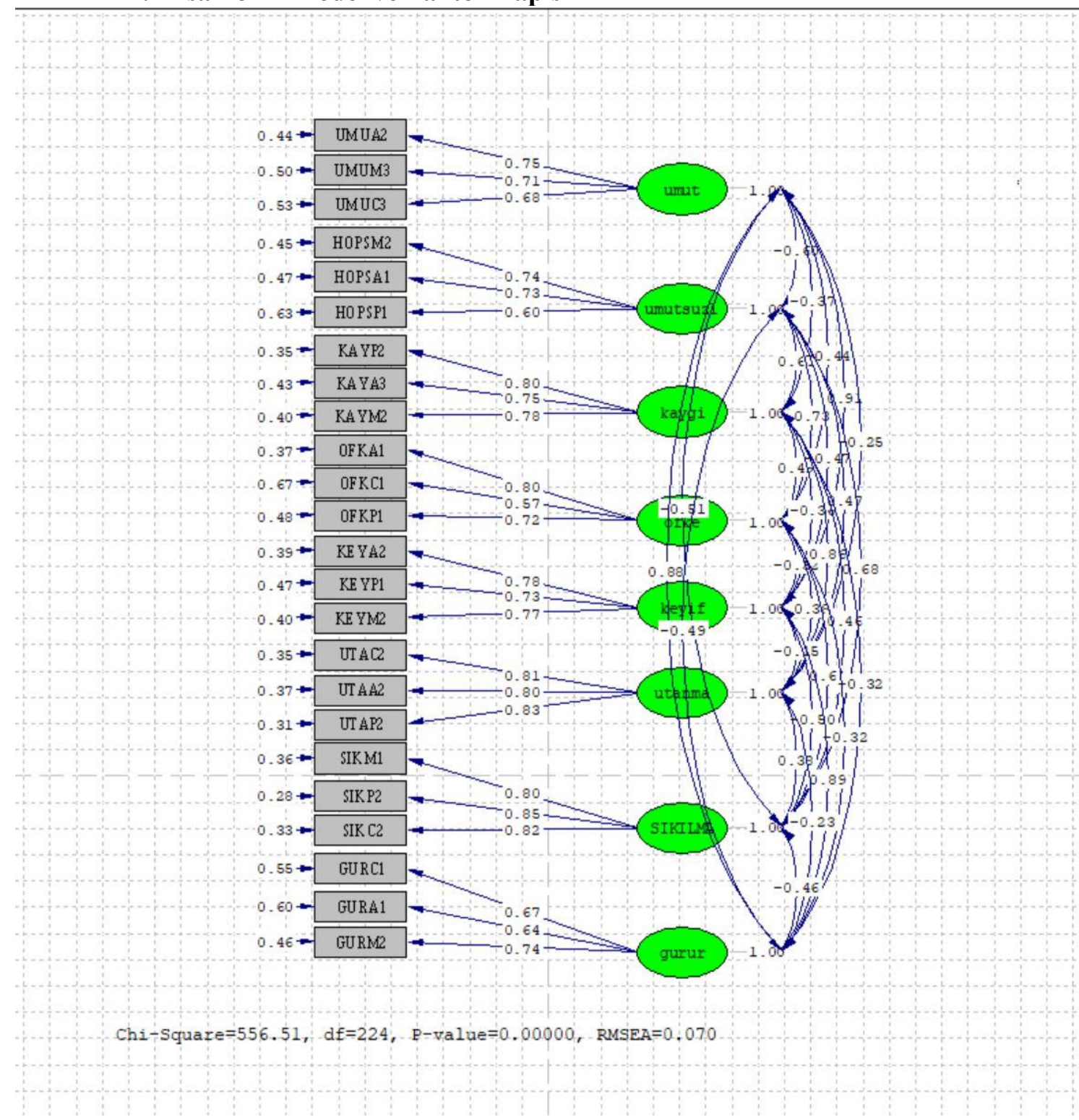

Ek 3: Kısa Form Güvenirlik ve Ortalama Açıklanan Varyans Değerleri

\begin{tabular}{lllllll}
\hline Faktör & $\begin{array}{l}\text { Madde } \\
\text { Kodu }\end{array}$ & Madde & $\begin{array}{l}\text { Faktör } \\
\text { Yükü }\end{array}$ & $\boldsymbol{\alpha}$ & CR & OAV \\
\hline GURUR & C1 & $\begin{array}{l}\text { Dersi takip edebileceğim } \\
\text { için kendimle gurur } \\
\text { duyuyorum. }\end{array}$ & 0,67 & 0,722 & 0,725 & 0,469 \\
& A1 & $\begin{array}{l}\text { Kendimle gurur } \\
\text { duyuyorum. }\end{array}$ & 0,64 & & & \\
\hline
\end{tabular}




\begin{tabular}{|c|c|c|c|c|c|c|}
\hline & M2 & $\begin{array}{l}\text { Derste gösterdiğim } \\
\text { başarılardan gurur } \\
\text { duyduğum için derse } \\
\text { devam etmeye motive } \\
\text { oluyorum. }\end{array}$ & 0,74 & & & \\
\hline \multirow[t]{3}{*}{ ÖFKE } & $\mathrm{A} 1$ & $\begin{array}{l}\text { Derste kendimi sinirli } \\
\text { hissediyorum. }\end{array}$ & 0,80 & 0,701 & 0,742 & 0,494 \\
\hline & $\mathrm{P} 1$ & $\begin{array}{l}\text { Öfkemin içimde } \\
\text { kabardığını } \\
\text { hissediyorum. }\end{array}$ & 0,72 & & & \\
\hline & $\mathrm{C} 1$ & $\begin{array}{l}\text { Dersin kalitesizliğini } \\
\text { düşündüğümde } \\
\text { öfkeleniyorum. }\end{array}$ & 0,57 & & & \\
\hline \multirow[t]{3}{*}{ UMUT } & $\mathrm{A} 2$ & $\begin{array}{l}\text { Derse karşı umut } \\
\text { doluyum. }\end{array}$ & 0,75 & 0,758 & 0,757 & 0,509 \\
\hline & $\mathrm{C} 3$ & $\begin{array}{l}\text { Konuyu anladığım için } \\
\text { kendime güveniyorum. }\end{array}$ & 0,68 & & & \\
\hline & M3 & $\begin{array}{l}\text { Başarılı olacağım ümidi } \\
\text { daha fazla gayret } \\
\text { göstermemi sağlıyor. }\end{array}$ & 0,71 & & & \\
\hline \multirow[t]{3}{*}{ KEYİF } & $\mathrm{A} 2$ & $\begin{array}{l}\text { Derste olmaktan keyif } \\
\text { alıyorum. }\end{array}$ & 0,78 & 0,802 & 0,804 & 0,578 \\
\hline & $\mathrm{P} 1$ & $\begin{array}{l}\text { Derse katılmaktan o } \\
\text { kadar zevk alıyorum ki } \\
\text { bu derse katılmak bana } \\
\text { enerji veriyor. }\end{array}$ & 0,73 & & & \\
\hline & M2 & $\begin{array}{l}\text { Dersten aldığım keyif } \\
\text { beni derse katılmaya } \\
\text { teşvik ediyor. }\end{array}$ & 0,77 & & & \\
\hline \multirow[t]{3}{*}{ KAYGI } & $\mathrm{P} 2$ & Derste geriliyorum. & 0,80 & 0,818 & 0,820 & 0,593 \\
\hline & M2 & $\begin{array}{l}\text { Yanlış bir şey } \\
\text { söylemekten korktuğum } \\
\text { için derste hiçbir şey } \\
\text { söylememeyi tercih } \\
\text { ediyorum }\end{array}$ & 0,78 & & & \\
\hline & A3 & Derste gerginim. & 0,75 & & & \\
\hline
\end{tabular}




\begin{tabular}{|c|c|c|c|c|c|c|}
\hline \multirow[t]{3}{*}{ UTANMA } & $\mathrm{P} 2$ & $\begin{array}{l}\text { Utandığım için kendimi } \\
\text { gergin ve çekingen } \\
\text { hissediyorum. }\end{array}$ & 0,83 & \multirow[t]{3}{*}{0,851} & 0,854 & \multirow[t]{3}{*}{0,661} \\
\hline & $\mathrm{C} 2$ & $\begin{array}{l}\text { Kendimi iyi ifade } \\
\text { edemediğim için } \\
\text { utanıyorum. }\end{array}$ & 0,81 & & & \\
\hline & A2 & $\begin{array}{l}\text { Derste utanmış } \\
\text { hissediyorum. }\end{array}$ & 0,80 & & & \\
\hline \multirow[t]{3}{*}{ SIKILMA } & $\mathrm{P} 2$ & $\begin{array}{l}\text { O kadar sıkıldım ki } \\
\text { uyanık kalmakta çok } \\
\text { zorlanıyorum. }\end{array}$ & 0,85 & \multirow[t]{3}{*}{0,861} & 0,863 & \multirow[t]{3}{*}{0,678} \\
\hline & $\mathrm{C} 2$ & $\begin{array}{l}\text { Sikıldığım için kafam } \\
\text { başka yerlerde }\end{array}$ & 0,82 & & & \\
\hline & M1 & $\begin{array}{l}\text { Ders çok sıkıcı olduğu } \\
\text { için dersten çıkıp } \\
\text { gidesim geliyor. }\end{array}$ & 0,80 & & & \\
\hline \multirow[t]{3}{*}{ UMUTSUZLUK } & M2 & $\begin{array}{l}\text { Umudumu kaybettiğim } \\
\text { için derse girmeye } \\
\text { enerjim yok. }\end{array}$ & 0,74 & \multirow[t]{3}{*}{0,704} & 0,733 & \multirow[t]{3}{*}{0,480} \\
\hline & A1 & $\begin{array}{l}\text { Bu dersi düşünmek beni } \\
\text { umutsuz hissettiriyor. }\end{array}$ & 0,73 & & & \\
\hline & $\mathrm{P} 1$ & $\begin{array}{l}\text { Konuyu anlamadığım } \\
\text { için kendimi dersten } \\
\text { kopmuş ve pes etmiş } \\
\text { hissediyorum. }\end{array}$ & 0,60 & & & \\
\hline
\end{tabular}

\section{EXTENDED ABSTRACT}

Emotions are the subject of studies in educational context, especially because of their possible role on learning. In the literature, it is stated that emotions affect learning, attention, cognition, memory, decision-making processes, learning strategies used by learners, selfregulated learning, commitment, academic performance and academic achievement (Hayat, Shateri, Amini \& Shokrpour, 2020; Immordino Yang \& Damasio, 2012; Obergriesser \& Stoeger, 2020; Park \& Lim, 2019; Pekrun, 2006; Pekrun \& Perry, 2014; Raccanello, Brondino, Crescentini, Castelli \& Calvo, 2021; Schrader \& Kalyuga, 2020; Wosnitza \& Volet, 2005; You \& Kang, 2014).

It is claimed that positive emotions are positively related to learning and performance, while negative emotions are negatively related to learning, motivation, and performance (Pekrun, 2006). But, it is also said that it would be appropriate to avoid generalizations such as the inference that positive emotions cause positive learning and performance and learning outcomes, and 
negative emotions cause negative outcomes. At this point, the importance of the context in which emotions are formed emerges. When the studies in the literature are examined in terms of the context of the learning environment, it is seen that most of the studies are done face-to-face. Considering that online learning environments are frequently used in education (Lajoie, Pekrun, Azevedo \& Leighton, 2019; Stephan, Gläser Zikuda \& Markus, 2019), it can be argued that research results on emotion are needed in this environment.

Achievement emotions are described that occur as a result of students' evaluations in the educational environment as emotions related to achievement and "emotions directly related to achievement activities or outcomes" (Pekrun, 2006; Pekrun et al., 2011). Emotions related to achievement outcomes are expressed as achievement emotions but later, the emotions that arise during an activity or practice were also evaluated in this category (Pekrun et al., 2011). In the context of the Control-Value Theory, emotions are classified according to their valence (negative or positive), activation levels (activating or pacifying) or object focus (emotions in learning environments can be related to achievement activities as well as emotions related to achievement outcomes). This classification of emotions in the academic environment is considered important to understand the effects of emotion on motivational and cognitive factors in learning (Peklaj \& Pecjak, 2011). In order to understand and measure these effects, Pekrun, Goetz, and Perry (2005) developed AEQ for emotions that they classified in educational context. AEQ is a multidimensional self-report-based instrument designed to assess emotions about achievement. In the questionnaire developed by Pekrun et al. (2005), there are three sections: (a) class-related emotions lesson, (b) learning related emotions, c) test related emotions. In the category of classrelated emotions, there are items for measuring the emotions that learners have experienced in the classroom environment. Accordingly, in this section, AEQ has pride (9 items), anxiety (12 items), enjoyment (10 items), anger (9 items), boredom (11 items) hope (8 items), hopelessness (10 items), shame (11 items) and eight factors and 80 items. Based on these points, this study has two purposes. The first is the validation of class-related section of AEQ in the context of online environment for preservice teachers. The second purpose is to make validity and reliability calculations by creating the short form of AEQ based on the findings of the first study.

The data for the validation of AEQ was obtained from 308 participants. $70 \%$ of the participants are women, 30\% are men; 32.4\% from Giresun University, 30.1\% RTE University, 14.6\% Muş Alparslan University, 8.1\% Artvin Coruh University, 9.01\% Amasya University and $5 \%, 5$ of them were from Trakya University. Maximum probability (ML) estimation method was used for confirmatory factor analysis (CFA) of AEQ. For the construct validity of the questionnaire, a single factor model, a four or three factor model and a second level factor analysis were used (Pekrun et al., 2005). To evaluate model fit, Chi-Square goodness of fit test, Root Mean Square Error of Approximation (RMSEA), Comparative Fit Index (CFI) and Normed Fit Index (NFI) were used. In the literature, if the RMSEA value is .05, the model shows a good fit, it is acceptable between .05 and .08 , and when below .08 shows poor fit . It is stated that if CFI / NFI / TFI values are greater than .95 , the fit is high, but if between .90 and .90 , it is acceptable fit and less than .90 show poor fit (Hu \& Bentler, 1999).

According to the results of the study for pride, all 3 models are validated. When the fit indices of the models are examined, RMSEA $=0.059, \mathrm{X} 2 / \mathrm{df}=2.05, \mathrm{CFI}=0.99, \mathrm{NFI}=0.98$ for single factor model, RMSEA $=0.023, \mathrm{X} 2 / \mathrm{df}=1.16$ for four-factor model, $\mathrm{CFI}=0.99, \mathrm{NFI}=$ $0.99, \mathrm{RMSEA}=0.045, \mathrm{X} 2 / \mathrm{df}=1.61, \mathrm{CFI}=0.99, \mathrm{NFI}=0.99$ for the second order model . When the fit indices are examined for enjoyment, RMSEA $=0.050, \mathrm{X} 2 / \mathrm{df}=1.76, \mathrm{CFI}=0.99, \mathrm{NFI}=$ 0.99 for single factor model; RMSEA $=0.085, \mathrm{X} 2 / \mathrm{df}=3.20, \mathrm{CFI}=0.99, \mathrm{NFI}=0.99$ for threefactor model, RMSEA $=0.085, \mathrm{X} 2 / \mathrm{df}=3.20, \mathrm{CFI}=0.99, \mathrm{NFI}=0.99$ for second-order model. The results for anger are RMSEA $=0.047, \mathrm{X} 2 / \mathrm{df}=1.69, \mathrm{CFI}=0.99, \mathrm{NFI}=0.98$ for one factor model; RMSEA $=0.029, \mathrm{X} 2 / \mathrm{df}=1.25, \mathrm{CFI}=0.99, \mathrm{NFI}=0.99$ for three-factor model; RMSEA $=0.029, \mathrm{X} 2 / \mathrm{df}=1.25, \mathrm{CFI}=0.99, \mathrm{NFI}=0.99$ for second order-model. The results for hope are, $\mathrm{RMSEA}=0.072, \mathrm{X} 2 / \mathrm{df}=2.60, \mathrm{CFI}=0.99, \mathrm{NFI}=0.98$ for the single factor model; for three- 
factor model, RMSEA $=0.087, \mathrm{X} 2 / \mathrm{df}=3.30, \mathrm{CFI}=0.99, \mathrm{NFI}=0.98$; for second order model, RMSEA $=0.087, \mathrm{X} 2 / \mathrm{df}=3.30, \mathrm{CFI}=0.99, \mathrm{NFI}=0.98$. The results for boredom are as follows: $\mathrm{RMSEA}=0.047, \mathrm{X} 2 / \mathrm{df}=1.66, \mathrm{CFI}=0.99, \mathrm{NFI}=0.99$ as single factor model, $\mathrm{RMSEA}=0.054$, $\mathrm{X} 2 / \mathrm{df}=1.91, \mathrm{CFI}=0.99, \mathrm{NFI}=0.99$ three factor model RMSEA $=0.054, \mathrm{X} 2 / \mathrm{df}=1.91, \mathrm{CFI}$ $=0.99, \mathrm{NFI}=0.99$ has emerged as a second-order model. When the fit indices of shame examined, it was found that RMSEA $=0.084, \mathrm{X} 2 / \mathrm{df}=3.19, \mathrm{CFI}=0.99, \mathrm{NFI}=0.98$ for single factor model RMSEA $=0.081, \mathrm{X} 2 / \mathrm{df}=3.00 \mathrm{CFI}=0.99, \mathrm{NFI}=0.99$ for three factor model, RMSEA $=0.081$, $\mathrm{X} 2 / \mathrm{df}=3.00, \mathrm{CFI}=0.99, \mathrm{NFI}=0.99$ for the second order model. The results for anxiety are RMSEA $=0.095, \mathrm{X} 2 / \mathrm{df}=3.76, \mathrm{CFI}=0.98, \mathrm{NFI}=0.97$ for single factor model, $\mathrm{RMSEA}=0.072$, $\mathrm{X} 2 / \mathrm{df}=2.59, \mathrm{CFI}=0.99, \mathrm{NFI}=0.98$ for three factor model, RMSEA $=0.072, \mathrm{X} 2 / \mathrm{df}=2.59$, $\mathrm{CFI}=0.99, \mathrm{NFI}=0.98$ for second order model. While the single factor model was confirmed for hopelessness and the results are, RMSEA $=0.088, \mathrm{X} 2 / \mathrm{df}=3.36, \mathrm{CFI}=0.98$ and NFI $=0.97$. $\mathrm{AEQ}$, except hopelessness, was verified with a three-factor structure for seven emotions, and a second-order factor analysis was performed, and it was found that the obtained fit values were between acceptable and good. Cronbach's alpha values ranged between 0.60 and 0.83 for confirmed three-factor models, while 0.79 for a single-factor of hopelessness. The composite reliability was found to be between 0.63 and 0.87 for three-factor models and 0.79 for singlefactor for hopelessness. According to these results, it can be said that the questionnaire is valid and reliable. The fit indices of the short form were determined as RMSEA 0.070, CFI: 0.96 and NFI: 0.94, and Cronbach Alpha value is 0.75. It has been concluded that the short form can also be used in emotion studies. 